IZA DP No. 9637

Subjective Well-being in China, 2005-2010:

The Role of Relative Income, Gender and Location

M Niaz Asadullah

Saizi Xiao

Emile Kok-Kheng Yeoh

January 2016 


\title{
Subjective Well-being in China, 2005-2010: The Role of Relative Income, Gender and Location
}

\author{
M Niaz Asadullah \\ University of Malaya, University of Reading, \\ SKOPE, IZA and SEED \\ Saizi Xiao \\ University of Malaya \\ Emile Kok-Kheng Yeoh
University of Malaya \\ Discussion Paper No. 9637 \\ January 2016 \\ IZA \\ P.O. Box 7240 \\ 53072 Bonn \\ Germany \\ Phone: +49-228-3894-0 \\ Fax: +49-228-3894-180 \\ E-mail: iza@iza.org
}

\begin{abstract}
Any opinions expressed here are those of the author(s) and not those of IZA. Research published in this series may include views on policy, but the institute itself takes no institutional policy positions. The IZA research network is committed to the IZA Guiding Principles of Research Integrity.

The Institute for the Study of Labor (IZA) in Bonn is a local and virtual international research center and a place of communication between science, politics and business. IZA is an independent nonprofit organization supported by Deutsche Post Foundation. The center is associated with the University of Bonn and offers a stimulating research environment through its international network, workshops and conferences, data service, project support, research visits and doctoral program. IZA engages in (i) original and internationally competitive research in all fields of labor economics, (ii) development of policy concepts, and (iii) dissemination of research results and concepts to the interested public.
\end{abstract}

IZA Discussion Papers often represent preliminary work and are circulated to encourage discussion. Citation of such a paper should account for its provisional character. A revised version may be available directly from the author. 


\title{
ABSTRACT \\ Subjective Well-being in China, 2005-2010: The Role of Relative Income, Gender and Location*
}

\begin{abstract}
We use data from two rounds of the Chinese General Social Survey (CGSS) to study the determinants of subjective well-being in China over the period 2005-2010 during which selfreported happiness scores show an increase across all income groups. Ordered probit regression analysis of well-being reveals large influence of gender, rural residency and household income. After controlling for demographic attributes, health, unemployment status, household size, agricultural hukou (household registration identity) and education status, household assets, the influence of past and future income and province dummies, we find that women, urban residents and people with higher income are happier in China. More schooling, better health and being employed are positively and significantly correlated with well-being. Sub-sample $s$ reveals that the rich only care about relative income whereas the effect of absolute income dominates in case of the poorer section. The influence of absolute income is larger among women compared to men and in turn explains why women, despite being poorer, are happier in China, conditional on socio-economic differences. On the other hand, rural residents are poorer than urban residents so that conditional on having the same income, there is no rural-urban happiness gap. Our results suggest that while further decline in poverty will enhance well-being in China, policies that reduce rural-urban and gender inequalities are also likely to boost well-being.
\end{abstract}

JEL Classification: $\quad 012,130,131$

Keywords: gender, happiness, inequality, poverty, unemployment, well-being

Corresponding author:

M Niaz Asadullah

Faculty of Economics and Administration

University of Malaya

Kuala Lumpur 50603

Malaysia

E-mail:m.niaz@um.edu.my

\footnotetext{
* This study is the outcome of the "The China Model: Implications of the Contemporary Rise of China (MOHE High-Impact Research Grant)" project UMC/625/1/HIR/MOHE/ASH/03. Data analysed in this paper come from the research project "Chinese General Social Survey (CGSS)" of the National Survey Research Center (NSRC), Renmin University of China. We appreciate the assistance in providing access to the data by NSRC. We also thank participants in the Chinese Economists Society (CES) 2015 conference for helpful comments and two anonymous referees of this journal for very helpful comments. The views expressed herein are the authors' own.
} 


\section{Introduction}

There is an ongoing debate over trends in and the determinants of subjective wellbeing in China. Income matters for happiness by helping to meet basic needs as well as sustaining well-being in times of economic shocks and crises (Johnson and Krueger, 2006). Yet people's perceived sense of happiness doesn't appear to have responded positively to improvements in macroeconomic conditions and a visible decline in income poverty. The country saw a four-fold increase in the level of per capita consumption and an unprecedented economic growth during 1980 to 2010. Despite the rapid rise in real income per capita and the human development index in recent years, subjective well-being appears not to have risen (Knight and Ramani, 2014). According to some studies, China has suffered a significant decrease in happiness during the last twenty years in the World Value Survey data (Easterlin et al., 2010). ${ }^{1}$ Equally, Appleton and Song (2008) document low levels of life satisfaction in urban China based on survey data for the year 2002. Knight, Song, and Gunatilaka (2009) argue that economic variables are relatively unimportant as determinants of happiness in China and instead emphasise psychological and sociological factors. Together the evidence on China from the 1990s fits the 'Easterlin paradox' in that economic growth and improved physical conditions did not add to the quality-of-life and average happiness. ${ }^{2}$

However Clark and Senik (2011) caution that the idea that growth will increase happiness in low-income countries cannot be rejected on the basis of the available evidence. ${ }^{3}$ They argue that time-series data doesn't reflect the same relationship because cross-country time-series analyses are based on aggregate measures, which are less reliable than those at the individual level. Moreover, using individual level data from the US, Kahneman and Deaton (2010) argue that emotional well-being satiates with high income whilst subjective evaluation scores do not. This suggests that even if money doesn't buy happiness, the lack of it is associated with emotional pain. For these reasons, more analysis of subjective measures of well-being using individual/survey data is necessary to document and build-up the evidence on the issue.

The empirical literature on the economics of subjective well-being has grown rapidly, and much is known about the determinants of happiness in China based on survey data. However, earlier studies on China have been at times narrow in terms of study population, for instance, focusing on some specific groups such as the elderly and urban residents (Knight and Gunatilaka, 2010; Smyth, Nielsen and Zhai, 2010; Wang,

\footnotetext{
${ }^{1} \mathrm{Wu}$ and $\mathrm{Li}$ (2013) examine the subjective consequence of rising income inequality amidst rapid economic growth in China. Based on the data from a nationally representative survey conducted in 2005, they show that, while personal income improves life satisfaction, local level income inequality has a negative effect on individuals' life satisfaction, but they did not look into the impact for different income groups.

${ }^{2}$ Empirical support for this also comes from the broader literature on happiness in developing countries. For instance, Easterlin and Angelescu (2009) find no significant relationship between improvement in happiness and the long term rate of growth of GDP per capita even when analysis is restricted to 9 developing and 11 transition economies which included China.

${ }^{3}$ Clark and Senik (2011) review the international evidence on the relationship between income growth and subjective well-being in developing countries, highlighting two important patterns: (a) income comparisons within countries do seem to affect subjective well-being, even in very poor countries; (b) adaptation may be more of a rich-country phenomenon.
} 
Cheng and Smyth, 2013) ${ }^{4}$. While there are studies galore exploring the absolute income effect, the number of studies that additionally test for and report relative income effects is small. ${ }^{5}$ Moreover a handful of high quality studies that look at relative income effect focus on urban residents (e.g. Appelton and Song, 2008; Smyth and Qian, 2008; Wang and VanderWeele, 2011; Liu and Shang, 2012), rural areas (e.g. Knight, Song, and Gunatilaka, 2009) or ethnic minorities (e.g. Mishra et al., 2014).

There are three additional possible explanations for why findings on the relationship between income and happiness in China are mixed in the earlier studies. First, economic growth has also seen a sustained rise in income inequality and falling absolute incomes at the bottom end of the income distribution in rural areas (Benjamin et al., 2005). This may have reduced happiness because individuals prefer equal society i.e. inequality belongs in their well-being function. ${ }^{6}$ In addition, in the absence of social mobility, the poor in China will view current inequality as a predictor of future relative poverty and hence remain dissatisfied in an unequal community. Therefore the poor may feel unhappy despite a rise in their absolute income in recent years. The dissatisfaction caused by growing inequality may attenuate the positive effect of income on happiness. Indeed some early studies (e.g. Brockmann, Delhey, Welzel and Yuan, 2009) describe happiness decline in China over the period 1990-2000 as the perceived loss of well-being among "frustrated achievers". ${ }^{7}$ At the same time, if social mobility is high, inequality (or higher income of the peers) can lead to a positive effect on subjective well-being (Graham and Felton, 2009). ${ }^{8}$ Second, the labour market in China has seen rising unemployment rates and decreasing labour force participation over the last two decades despite sustained GDP growth (Liu, 2012). Contrary to published government data, independent assessment confirms much higher unemployment rate and lower work participation rate, ${ }^{9}$ particularly among women, in recent years (Feng, Hu and Moffitt, 2015). This may weaken the average relationship between happiness and rising per capita income. Third, the observed relationship between happiness and income could

\footnotetext{
${ }^{4}$ For a review of the older studies, see Chen and Davey (2008); studies exclusively on China are reviewed in Chen (2015).

5 Developing country studies that confirm the role of comparison income as a determinants of subjective well-being are Knight, Song and Gunatilaka (2009) and Knight and Gunatilaka (2010) for China, Fafchamps and Kebede (2008) for Ethiopia, Camfield and Esposito (2014) and Corazzini, Esposito and Majorano (2012) for multi-country studies.

${ }^{6}$ For urban China, Smyth and Qian (2008) find that those who perceive income distribution to be unequal report lower levels of happiness.

${ }^{7}$ Similar evidence is available for two transition economies, Peru and Russia, where relative instead of absolute income differences were found to be more important as determinant of happiness (Graham and Pettinato, 2002). Also see Kingdon and Knight (2007) for South Africa, Carlsson, Gupta and Johansson-Stenman (2009) for India, Ravallion and Lokshin (2010) for Malawi, Asadullah and Chaudhury (2012) for Bangladesh and Guillen-Royo (2011) for Peru. For a review of the international evidence on relative income effects on subjective well-being, see Clark, Frijters and Shields (2008) and Verme (2013).

${ }^{8}$ Consistent with this view, Jiang et al (2012) found that urban residents in China are happier when their incomes increase within their group's income distribution.

${ }^{9}$ For instance, Giles et al (2005) reported unemployment to be as high as $14.0 \%$ among urban permanent residents in 2002. For a critical discussion on the reliability of published government labor statistics, see Cai et al (2013).
} 
be driven by a "focusing illusion" (Deaton, 2008). ${ }^{10}$ In periods of continuous economic growth, increases in income may generate no increase in happiness. ${ }^{11}$ Income may be assessed relative to others or to one's past income (Clark, Frijters and Shields, 2008). In such settings, appropriate controls for social comparisons (e.g. relative living standard compared to others in the locality as well as compared to one's past) are important, but specification of the happiness function in earlier studies vary in this respect.

For the above reasons, the exact effect of income on subjective well-being in China remains a contested issue in the literature. Higher income aspirations can reduce people's utility leaving the relationship between income and happiness unchanged if, following processes of adaptation and social comparison, income aspirations increase with people's income as well as income of others in the community. Individual wellbeing depends on the absolute level of income and consumption as well as its value relative to one's aspirations and income of others in the community. Moreover, it is possible that the happiness-income relationship has changed in recent years in a way not captured by older surveys and studies. ${ }^{12}$ Indeed, a recent study by Easterlin et al (2012) concludes that the long-term movement of life satisfaction scores in China during 1990-2010 has followed a U-shaped pattern, showing a sign of recovery in recent years. ${ }^{13}$ China's fast-growing and increasingly unequal economy provides an ideal context to revisit the importance of absolute income as the fundamental determinant of happiness. Therefore, in this paper, we revisit the debate over absolute vs. relative incomes as correlates of subjective well-being using two rounds of the Chinese General Social Survey (CGSS) data spanning the period 2005-2010. ${ }^{14}$ Since the significance of aspiration, relative income, and labour market changes (such as unemployment rate and gender gap in wages) are likely to vary by location, we study

\footnotetext{
${ }^{10}$ Focusing illusion refers to a cognitive bias that occurs when people place too much importance on one aspect of an event, exaggerating its importance, and causing an error in accurately predicting the utility of a future outcome. For instance, an overall happiness question elicits a global evaluation of one's life as opposed to experienced happiness (Dolan and Metcalfe, 2012). Therefore the former induces a form of focusing illusion, by drawing respondents' attention to their relative standing in the distribution of material well-being (Kahneman, Krueger, Schkade, Schwarz and Stone, 2006).

${ }^{11}$ This hypothesis is consistent with the micro-level evidence from the German Socioeconomic Panel by Di Tella, Haisken-De New and MacCulloch (2010) who regress life satisfaction on income and on several lags of income and find that life satisfaction adapts completely to income within four years, so income growth provides only a temporary boost to life satisfaction. Similarly, Haushofer, Reisinger and Shapiro (2015) found that the happiness of individuals who benefited from a cash transfer program in Kenya, including those who did not receive the transfer, had returned close to its pre-transfer value after one year.

${ }^{12}$ For instance, recent cross-country evidence shows that although mean happiness has not increased significantly in high income countries, it has improved considerably in low income nations for which data are available (Veenhoven and Hagerty, 2006).

${ }^{13}$ Easterlin et al rely on data drawn from six mostly urban surveys conducted by five different organisations.

${ }^{14}$ We are aware of five studies that have looked into happiness issues in China using CGSS data. Wang and VanderWeele (2001) employed data from 2003 CGSS but only focused on urban respondents. Wang and Xie (2015) used data from 2003, 2006 and 2008 rounds of the CGSS, but the authors focused on the role of employment sector (public vs private) as a determinant of happiness. Chyi and Mao (2011) used the 2005 round, but focused on happiness among the elderly population. Liu, Xiong and $\mathrm{Su}$ (2013) used multiple-rounds of CGSS data to analyze the trends in happiness, but don't formally examine the roles of absolute and comparison incomes. Lastly Wang, Pan and Luo (2015) used the CGSS 2006 round to examine the impact of income inequality on happiness. For a recent review of the literature on China, see Knight and Ramani (2014).
} 
happiness separately for rural and urban residents as well as men and women. We therefore contribute to the literature by documenting heterogeneous gradients of income-happiness in China. Other specific contributions include further evidence on a modified version of Easterlin's hypothesis -- we confirm the existence of a relationship between income and well-being among those whose basic needs have not been met, but showing that beyond a certain income threshold, further income is uncorrelated to well-being.

The rest of the paper is organised as follows. Section 2 discusses the methodology while the sample and data are described in Section 3. The main results are presented in Section 4, followed by the conclusion in Section 5.

\section{Methodology}

Subjective well-being is widely considered as a satisfactory empirical approximation to individual utility in the economics literature (Oswald, 1997; Di Tella and MacCulloch, 2006; Kahneman and Krueger 2006; Blanchflower and Oswald, 2008). In keeping with existing studies in the literature, we estimate the happiness function for China in the following form:

$W_{i}^{*}=a_{1}+\ln (y i) b_{1}+P_{i} c_{1}+Z_{i} d_{1}+u_{i}$

where following Kahneman and Deaton $(2010), \ln \left(\mathrm{y}_{\mathrm{i}}\right)$ is the logarithm of per capita income of the respondent's household (i.e. last year's total household income divided by number of family members), ${ }^{15} P_{i}$ a vector of personal characteristics such as age, minority ethnicity, ${ }^{16}$ marital status, educational attainment, number of children and $Z_{i}$ a vector of location dummies. $W_{i} *$ is a latent variable as what is observed is different categories of an ordered categorical variable. Subjective well-being in CGSS data is measured by using responses to the question, "Generally speaking, how do you personally feel about your life?" on a scale of 1 to 5 where 1 is being very unhappy; ... 3 = neither happy, nor unhappy; ...; 5 is being very happy (Chyi and Mao, 2011). Hence equation (i) is estimated using an ordered probit estimator since there is an inherent ordering in our measure of well-being, $W_{i}{ }^{17}$

The income variable, $y_{i}$, could be picking up the effect of other variables such as economic shocks, poor health status, and influence of geography (e.g. distance from coastal areas). Therefore, we additionally control for economic shock (e.g.

\footnotetext{
${ }^{15}$ Oshio, Nozaki, and Kobayashi (2013) find the association between relative income and happiness to be stronger for individual income than family income in China. However individual income is subject to greater measurement error than household income. Hence we rely on the latter in this study, as is also done by other researchers (e.g. Knight and Gunatilaka, 2011).

${ }^{16}$ There are 56 ethnicities in China where Han is the dominant ethnicity. The other 55 ethnicities including Man, Meng, Zang, Zhuang and so on are considered minority groups (Harrell, 1996). In CGSS 2005 and 2010 data, Han ethnicity has a sample population share of $93.89 \%$ and $90.49 \%$ respectively. The lifestyle and attitudes of ethnic minorities may positively affect their happiness compared to the majority Han group (Knight et al., 2014).

${ }^{17}$ An alternative to the ordered probit regression approach is the structural equation modelling which allows for a simultaneous treatment of both latent variable and the observed correlates (e.g. age and family size) within one framework (Bollen, 1989; Tang et al. 2013; Tang et al., 2015). Li et al. (2014) followed this approach to study the impact of environmental quality on happiness in China.
} 
unemployment ${ }^{18}$ ), agricultural hukou ${ }^{19}$ and self-reported health status ${ }^{20}$ of the respondent as well as a full set of location dummies. An estimate of the correlation between absolute income and happiness obtained from equation (i) can also proxy for factors such as income relative to others in the locality and income relative to that in the past. The correlation between happiness and income may be the outcome of comparison of one's own income with one's previous incomes or the economic status of others in the community (Deaton, 2008). If so, controlling for relative living standard - compared to others in the locality and/or compared to one's past economic status - we don't expect a correlation between happiness and income. Therefore we expand equation (i) in the following way:

$W_{i}^{*}=a_{2}+\ln \left(y_{i}\right) b_{2}+P_{i} c_{2}+Z_{i} d_{2}+E_{i} e_{2}+e_{i}$

Where $E_{i}$ is a vector of relative economic position and income related expectations. The main hypothesis tested in equation (ii) relates to the importance of income. We expect absolute income to be positively linked to happiness, but only until basic needs are met. For individuals with income sufficiently high to escape food insecurity and absolute poverty, additional income should not matter for happiness. To test this directly we estimate another version of equation (ii) where we additionally control for household economic status:

$W_{i}^{*}=a_{3}+\ln \left(y_{i}\right) b_{3}+P_{i} c_{2}+Z_{i} d_{3}+E_{i} \mathrm{e}_{3}+X_{i} f_{3}+v_{i}$

where the vector $\mathrm{X}_{\mathrm{i}}$ comprises household specific asset variables including housing area, having a car or not and number of houses.

In order to model relative income effects, we used two questions from the CGSS. One question asked respondents to indicate on a scale of 1-5, their own family economic status relative to others in the same city. The second question was about each respondent's perceived socio-economic position in the society 10 years ago, at present and 10 years later. We used subjective responses to both questions as measures of relative income. In addition, we considered an alternative approach using mean income of the community in the well-being function as a measure of relative income of "others". This is not our preferred measure of relative income since the CGSS does not contain information on income of all the households in sample sites and their exact identity. ${ }^{21} \mathrm{We}$ nonetheless discuss the findings for comparison purposes, albeit

\footnotetext{
${ }^{18}$ We followed Feng, Hu and Moffitt (2015) and divided the data on labor force participation and employment status into three categories: in labor force and employed, in labor force but unemployed, and not in labor force.

${ }^{19}$ In China, every citizen has to be officially registered based on the Household Registration System known as "hukou" in Chinese. Agricultural hukou usually refers to a rural household registration status whilst a non-agricultural one usually refers to an urban registration status. Since the economic reforms of late 1970s, the hukou system has gradually evolved toward a weakening of the rural/urban divide, but a strengthening of the geographic element. Today, hukou captures local citizenship and is an important mechanism determining entitlements to various social services, which are mainly funded by local governments (Chan and Buckingham, 2008). For studies on the relationship between happiness and hukou, see Jiang, Lu and Sato (2012) and Tani (2015).

${ }^{20}$ In happiness research, current health condition is often measured through subjective evaluations e.g. see Graham (2008).

${ }^{21}$ Knight et al. (2009) reported that 68 percent of survey respondents in rural China considered individuals in their own village as their main comparison group. Similarly, Mangyo and Park (2011)
} 
acknowledging the data limitation. Lastly we used responses to a question about economic status 10 years later to control for expectations and aspirations. ${ }^{22}$

It should be noted that income is often viewed as an endogenous variable in the wellbeing equation. Unmeasured personality differences (e.g. optimism and extrovert personality) and health status may simultaneously determine happiness and income therefore confounding the estimated effect of absolute income. Recent research however reported a significant and positive income effect on happiness even after dealing with potential endogeneity biases and the possibility of reverse causality (e.g. Powdthavee, 2009; Li, Liu, Ye and Zhang, 2014). ${ }^{23}$ Nonetheless we address some of these concerns in our analysis. In the CGSS dataset, we have information on exposure to adverse economic shocks and health status of the respondent and these are already controlled for in equation (i). However, the CGSS does not have information on personality traits of individuals. One solution to this is to instrument household income using information on household assets. ${ }^{24}$ But assets may directly impact happiness independent of their contribution to household income. Therefore we include these as additional controls in equation (iii). In sum, while we don't directly address the problem of endogeneity bias in the absolute income effect, we significantly reduce scope for bias by introducing a rich set of controls in our regression model such as health status, unemployment status, relative economic position, perceived change in economic status over time and household assets.

Lastly, the ordered probit model estimates a single equation over all levels of the dependent variable under the assumption of proportional odds or parallel regression. Therefore we considered an alternative procedure, the generalised ordered logit model, which does not require the assumption of parallel regression to hold. When estimated, results specific to the main variables of interest - absolute and relative income measures - remained broadly unchanged in almost all equations. Therefore we did not report these and instead used ordered probit estimates throughout.

\section{Data and Sample Description}

Data used in this study comes from the recent Chinese General Social Survey (CGSS), a well-known nationally representative large data collection project in

identified village reference group as appropriate for residents living in close proximity in rural China while relatives and classmates were salient reference population for urban residents.

${ }^{22}$ This approach is similar to Knight, Song and Gunatilaka (2009) who used 2002 survey data to model relative income effect in terms of comparisons within the village and over time (past and expected future incomes).

${ }^{23}$ As a matter of fact, Powdthavee (2009) instrumenting for income and allowing for unobserved heterogeneity leads to a much bigger estimated income effect compared to the estimate in the naive specification. Furthermore, using data on restricted windfall income as a substitute for household income, Ambrey and Fleming (2014) found no evidence against the exogeneity of windfall income and that the causal effect of income on life satisfaction is substantially higher when restricted windfall income is used.

${ }^{24}$ Another strategy is to use information on communist party membership (CCP) since it is a strong predictor of income in China (Appleton et al., 2009). However evidence also indicates that CCP is a strong determinant of happiness in China (e.g. Knight et al., 2009) and hence is not a valid excluded instrument. We additionally experimented with parental party membership. Multiple instruments (i.e. father's and mother's party membership) allowed a formal test of instrument validity in a two-stage least square model. However, once again, party membership turned out to be correlated with the error term - the null of Sargan-Hansen test of over-identifying restrictions was rejected. 
China. ${ }^{25}$ The 2010 CGSS covered 11783 households $(38.71 \%$ of them from rural areas) in 31 provinces (excluding Hong Kong, Macau and Taiwan) while the 2005 round included 10372 respondents $(41.21 \%$ from rural areas) from 28 provinces. Three provinces (Xizang, Qinghai and Ningxia) in the 2010 round were not included in the 2005 round. Our research is based on data from both these rounds.

Table 1 reports mean happiness scores by income quintiles. Two patterns are noteworthy. First, in 2010, the reported score is 3.77, significantly up from 3.41 in 2005. Compared to older studies, the overall level of happiness in the CGSS data is high (e.g. see Appleton and Song, 2008). Second, there's a clear monotonic increase in the happiness score across income quintiles for all sub-samples, rural, urban, male and female, and the difference between 2010 and 2005 was always statistically significant. $^{26}$ This is important considering the fact that the period 2005-2010 saw further progress in poverty reduction (headcount poverty reduced from $15.8 \%$ in 2005 to $9.2 \%$ in 2010) while inequality remained high (with a gini of 0.42 ). ${ }^{27}$

Table 1: Mean Score of Happiness by Income Quintiles

\begin{tabular}{lccccccc}
\hline \multirow{2010}{*}{} & & Overall & $\mathbf{1}^{\text {st }}$ & 2nd & 3rd & $\mathbf{4}^{\text {th }}$ & $\mathbf{5 t h}^{\text {th }}$ \\
\cline { 3 - 8 } & Whole & 3.77 & 3.44 & 3.67 & 3.78 & 3.93 & 4.04 \\
& Urban & 3.81 & 3.38 & 3.65 & 3.77 & 3.92 & 4.04 \\
& Rural & 3.69 & 3.47 & 3.70 & 3.79 & 3.96 & 4.02 \\
& Female & 3.77 & 3.41 & 3.67 & 3.82 & 3.96 & 4.07 \\
& Male & 3.76 & 3.47 & 3.68 & 3.73 & 3.90 & 4.01 \\
& & & & & & & \\
& Whole & 3.41 & 3.10 & 3.33 & 3.45 & 3.58 & 3.70 \\
& Urban & 3.45 & 2.96 & 3.23 & 3.38 & 3.56 & 3.69 \\
& Rural & 3.37 & 3.15 & 3.40 & 3.57 & 3.68 & 3.83 \\
& Female & 3.41 & 3.10 & 3.33 & 3.48 & 3.57 & 3.74 \\
& Male & 3.42 & 3.10 & 3.33 & 3.42 & 3.59 & 3.66 \\
\hline
\end{tabular}

Note: Data is from the Chinese General Social Survey (CGSS).

\footnotetext{
${ }^{25}$ The CGSS is a nationwide, repeated, cross-sectional general survey that was launched jointly in 2003 by Renmin University and Hong Kong University of Science and Technology.

${ }^{26}$ This has been verified using two-tailed t-tests; differences in mean scores were significant at the $1 \%$ level.

${ }^{27}$ Figures are from the World Development Indicators (WDI) data base of the World Bank.
} 
Table 2: Percentage of Respondents by Level of Happiness, Overall and by Income

Quintiles

\begin{tabular}{|c|c|c|c|c|c|c|c|}
\hline \multirow{3}{*}{2010} & & Sample share (\%) & 1st & 2nd & $3^{\text {rd }}$ & 4th & 5th \\
\hline & 1 & 2.12 & 4.91 & 2.38 & 1.29 & 1.06 & 0.69 \\
\hline & 2 & 7.77 & 14.63 & 8.98 & 7.43 & 4.33 & 2.91 \\
\hline \multirow{13}{*}{2005} & 3 & 17.62 & 23.31 & 20.56 & 18.96 & 14.00 & 10.67 \\
\hline & 4 & 56.48 & 46.14 & 54.96 & 56.78 & 61.78 & 63.51 \\
\hline & 5 & 16.01 & 11.01 & 13.11 & 15.53 & 18.83 & 22.22 \\
\hline & $\mathbf{N}$ & 10235 & 2098 & 2349 & 1777 & 1986 & 2025 \\
\hline & Mean Happiness & 3.77 & 3.44 & 3.67 & 3.78 & 3.93 & 4.04 \\
\hline & & Sample share (\%) & $1^{\text {st }}$ & $2^{\text {nd }}$ & $3^{\text {rd }}$ & $4^{\text {th }}$ & $5^{\text {th }}$ \\
\hline & 1 & 1.42 & 3.12 & 1.15 & 1.03 & 0.80 & 0.88 \\
\hline & 2 & 7.72 & 15.69 & 8.87 & 5.87 & 3.96 & 2.41 \\
\hline & 3 & 44.56 & 50.25 & 49.58 & 45.48 & 40.66 & 33.19 \\
\hline & 4 & 40.55 & 29.46 & 36.71 & 42.46 & 45.70 & 52.85 \\
\hline & 5 & 5.75 & 1.49 & 3.68 & 5.16 & 8.88 & 10.67 \\
\hline & $\mathbf{N}$ & 9674 & 2020 & 2525 & 1260 & 2501 & 1368 \\
\hline & Mean Happiness & 3.41 & 3.10 & 3.33 & 3.45 & 3.58 & 3.70 \\
\hline
\end{tabular}

Note: Data is from the Chinese General Social Survey (CGSS).

Table 2 shows the complete distribution of sample respondents by level of happiness and income quintiles. In the 2010 round, the proportion of respondents opting for the highest two of five possible levels of subjective well-being was $72.49 \%$ while the proportion reporting the lowest two was only $9.89 \%$. However, there is considerable variation across the quintiles of income per capita: whereas $57.15 \%$ in the lowest quintile reported happiness in the range of 4-5 points, the figure for the highest quintile was $85.73 \%$. When the categories of happiness were converted into cardinal values (ranging from a score of 5 for "very happy" down to 1 for "very unhappy"), the mean score (3.77 for the sample as a whole) rose monotonically from 3.44 in the lowest to 4.04 in the highest income quintile. The patterns are similar for 2005. Therefore, whilst there is a positive correlation between income and life happiness, there is much more to subjective well-being than what is explained by absolute household income.

Table 3: The Percentage of Respondents by Level of Happiness and by Comparison of Own Family Economic Status w.r.to Others in the Same City

\begin{tabular}{|c|c|c|c|c|c|c|c|}
\hline & & Sample share (\%) & $\begin{array}{c}\text { Far } \\
\text { Below }\end{array}$ & Below & Average & Above & Far Above \\
\hline \multirow{8}{*}{2010} & 1 & 2.12 & 12.24 & 2.57 & 0.47 & 0.91 & \\
\hline & 2 & 7.77 & 22.32 & 12.07 & 3.60 & 1.82 & 10.26 \\
\hline & 3 & 17.62 & 24.87 & 23.59 & 14.40 & 5.93 & 12.82 \\
\hline & 4 & 56.48 & 32.78 & 50.97 & 62.80 & 63.85 & 43.59 \\
\hline & 5 & 16.01 & 7.78 & 10.80 & 18.72 & 27.48 & 33.33 \\
\hline & $\mathbf{N}$ & 10235 & 784 & 3463 & 5054 & 877 & 57 \\
\hline & Mean Happiness & 3.77 & 3.02 & 3.55 & 3.96 & 4.15 & 4.00 \\
\hline & & Sample share (\%) & $\begin{array}{c}\text { Far } \\
\text { Below }\end{array}$ & Below & Average & Above & Far Above \\
\hline \multirow[t]{7}{*}{2005} & 1 & 1.42 & 3.84 & 0.62 & 0.62 & 1.53 & 2.63 \\
\hline & 2 & 7.72 & 20.05 & 6.24 & 3.01 & 2.14 & 2.63 \\
\hline & 3 & 44.56 & 52.31 & 52.79 & 38.33 & 22.82 & 15.79 \\
\hline & 4 & 40.55 & 21.57 & 36.38 & 50.73 & 59.26 & 57.89 \\
\hline & 5 & 5.75 & 2.22 & 3.97 & 7.31 & 14.24 & 21.05 \\
\hline & $\mathbf{N}$ & 9674 & 2160 & 2900 & 3885 & 653 & 76 \\
\hline & Mean Happiness & 3.41 & 2.98 & 3.37 & 3.61 & 3.83 & 3.92 \\
\hline
\end{tabular}


Table 4: Percentage of Respondents by Level of Happiness and by Comparison of Current Self-rated Class in Society with Status 10 years Ago

\begin{tabular}{|c|c|c|c|c|c|}
\hline & & Sample share $(\%)$ & Worse & Same & Better \\
\hline \multirow[t]{7}{*}{2010} & 1 & 2.12 & 5.41 & 2.63 & 0.91 \\
\hline & 2 & 7.77 & 13.38 & 8.87 & 5.55 \\
\hline & 3 & 17.62 & 22.03 & 18.94 & 15.59 \\
\hline & 4 & 56.48 & 48.04 & 54.45 & 60.05 \\
\hline & 5 & 16.01 & 11.15 & 15.11 & 17.90 \\
\hline & $\mathbf{N}$ & 10235 & 1480 & 3348 & 5407 \\
\hline & Mean Happiness & 3.77 & 3.46 & 3.71 & 3.88 \\
\hline \multirow{8}{*}{2005} & & Sample share $(\%)$ & Worse & Same & Better \\
\hline & 1 & 1.42 & 3.18 & 0.96 & 0.87 \\
\hline & 2 & 7.72 & 20.15 & 6.50 & 2.70 \\
\hline & 3 & 44.56 & 53.86 & 52.00 & 31.75 \\
\hline & 4 & 40.55 & 19.99 & 36.77 & 55.33 \\
\hline & 5 & 5.75 & 2.82 & 3.77 & 9.34 \\
\hline & $\mathbf{N}$ & 9674 & 1916 & 3846 & 3912 \\
\hline & Mean Happiness & 3.41 & 2.99 & 3.36 & 3.70 \\
\hline
\end{tabular}

Note: Data is from the Chinese General Social Survey (CGSS).

Respondents to the CGSS were asked to report their current living standard in terms of position in the society as well as 10 years ago. In addition, respondents were asked to report their perceived status over the next 10 years. All three questions employed a 10-point response scale. We used responses to these questions to construct indicator variables capturing perceived change w.r.t. the past as well as expected change w.r.t. the future. ${ }^{28}$ Table 3 cross-tabulates this data with happiness scores, presenting data on the percentage of respondents by level of happiness and by comparison of family economic status with local average level. On the other hand, Table 4 tabulates happiness across living standard in the past (10 years ago in the 2010 round; 3 years ago in the 2005 round).

Table 3 shows a skewed distribution around the average status with the majority, $41.49 \%$, regarding their living standard as being below average and only $9.13 \%$ as above (in the 2005 data, the figures are $52.31 \%$ and $7.54 \%$ respectively). The proportion reporting happiness in the range of 4-5 points rises monotonically with relative living standard, from $40.56 \%$ in the lowest category to $76.92 \%$ in the highest (in the 2005 CGSS, the figures are $23.79 \%$ and $78.94 \%$ respectively). It is evident that the feeling of relative deprivation by comparison with others in their locality affects well-being of respondents in our sample. On the other hand, the proportion reporting happiness in the range of 1-2 points falls from $34.56 \%$ to $10.26 \%$ as we move from the lowest to the highest comparison category (23.89\% to $5.26 \%$ in the 2005 data).

In sum, the discussion in this section suggests that non-income correlates of wellbeing and relative economic position are likely to be relevant for individuals in a developing income country like China. Overall, we intend to answer the following

\footnotetext{
${ }^{28}$ The exact question in the 2010 CGSS is as follows: "In our society, some groups remain at the top class while some groups are at the bottom level. In the following ladder, ' 10 ' presents the highest class while ' 1 ' refers to the lowest one. (a) Which class are you in currently? (b) Which class were you in ten years ago? (c) Which class will you be in ten years later? In the 2005 CGSS data, comparison is with respect to status 3 years ago/later
} 
questions: (i) Is the effect of income dominated by that of relative income? (ii) How does relative income effect vary across income levels? (iii) Is income effect dominated by concerns for attaining basic needs of the households? We explore these formally in the next section.

\section{Main Results}

\subsection{Full sample analysis}

Table 5 reports estimates of the happiness function for the 2010 and 2005 CGSS data. The first column presents estimates of well-being function obtained from a parsimonious model (equation i) where we only control for the respondent's age, agesquared, gender, ethnicity, marital status, educational attainment, number of children, household per capita income and location. The second column includes controlling for health, agricultural hukou and unemployment status. Column 3 expands the wellbeing function by including measures of comparison and aspiration incomes. The specification reported in column 4 adds controlling for household assets (house area, number of houses and owning a car) as proxies for basic needs. 
Table 5: Ordered Probit Estimates of the Determinants of Well-being in China, 2005-

\begin{tabular}{|c|c|c|c|c|c|c|c|c|}
\hline \multirow[b]{3}{*}{ Personal Characteristics } & \multicolumn{4}{|c|}{2010} & \multicolumn{4}{|c|}{2005} \\
\hline & (1) & (2) & (3) & (4) & (1) & (2) & (3) & (4) \\
\hline & & & & & & & & \\
\hline Age & $\begin{array}{c}-.052 * * * \\
(10.93)\end{array}$ & $\begin{array}{c}-.046 * * * \\
(9.44)\end{array}$ & $\begin{array}{c}-.038 * * * \\
(7.70)\end{array}$ & $\begin{array}{c}-.039 * * * \\
(7.80)\end{array}$ & $\begin{array}{c}-.062 * * * \\
(11.71)\end{array}$ & $\begin{array}{c}-.054 * * * \\
(10.02)\end{array}$ & $\begin{array}{c}-.047 * * * \\
(8.63)\end{array}$ & $\begin{array}{c}-.046^{* * * *} \\
(8.09)\end{array}$ \\
\hline Age square/100 & $\begin{array}{l}.057 * * * \\
(12.01)\end{array}$ & $\begin{array}{l}.056 * * * \\
(11.39)\end{array}$ & $\begin{array}{c}.049 * * * \\
(9.96)\end{array}$ & $\begin{array}{l}.050 * * * \\
(10.04)\end{array}$ & $\begin{array}{l}.062 * * * \\
(11.50)\end{array}$ & $\begin{array}{l}.057 * * * \\
(10.38)\end{array}$ & $\begin{array}{c}.049 * * * \\
(8.93)\end{array}$ & $\begin{array}{c}.048 * * * \\
(8.38)\end{array}$ \\
\hline Female & $\begin{array}{c}.078 * * * \\
(3.44)\end{array}$ & $\begin{array}{c}120 * * * \\
(5.08)\end{array}$ & $\begin{array}{c}112 * * * \\
(4.68)\end{array}$ & $\begin{array}{c}112 * * * \\
(4.67)\end{array}$ & $\begin{array}{l}.043 * \\
(1.86)\end{array}$ & $\begin{array}{c}.077 * * * \\
(3.24)\end{array}$ & $\begin{array}{c}.039 \\
(1.63)\end{array}$ & $\begin{array}{l}.048 * \\
(1.92)\end{array}$ \\
\hline Minority & $\begin{array}{c}123^{* * *} * \\
(2.60)\end{array}$ & $\begin{array}{l}.104^{* *} \\
(2.18)\end{array}$ & $\begin{array}{c}.056 \\
(1.17)\end{array}$ & $\begin{array}{c}.042 \\
(0.87)\end{array}$ & $\begin{array}{c}.197^{* * * *} \\
(3.71)\end{array}$ & $\begin{array}{c}.177 * * * \\
(3.32)\end{array}$ & $\begin{array}{c}150 * * * \\
(2.78)\end{array}$ & $\begin{array}{c}.156^{* * * *} \\
(2.77)\end{array}$ \\
\hline Married & $\begin{array}{c}.398 * * * \\
(7.97)\end{array}$ & $\begin{array}{c}.362 * * * \\
(7.23)\end{array}$ & $\begin{array}{c}.322 * * * \\
(6.39)\end{array}$ & $\begin{array}{c}.315^{* * *} \\
(6.13)\end{array}$ & $\begin{array}{c}.485 * * * \\
(9.39)\end{array}$ & $\begin{array}{c}.481 * * * \\
(9.22)\end{array}$ & $\begin{array}{c}.496^{* * * *} \\
(9.38)\end{array}$ & $\begin{array}{c}.452 * * * \\
(8.23)\end{array}$ \\
\hline Divorced & $\begin{array}{c}-.279 * * * \\
(3.18)\end{array}$ & $\begin{array}{c}-.289 * * * * \\
(3.30)\end{array}$ & $\begin{array}{c}-.230 * * * \\
(2.59)\end{array}$ & $\begin{array}{c}-.218^{* *} \\
(2.43)\end{array}$ & $\begin{array}{c}-.329 * * * \\
(3.14)\end{array}$ & $\begin{array}{c}-.344 * * * \\
(3.26)\end{array}$ & $\begin{array}{c}-.237 * * \\
(2.21)\end{array}$ & $\begin{array}{c}-.268 * * \\
(2.38)\end{array}$ \\
\hline Widowed & $\begin{array}{l}-.002 \\
(0.03)\end{array}$ & $\begin{array}{l}-.034 \\
(0.51)\end{array}$ & $\begin{array}{c}.011 \\
(0.16)\end{array}$ & $\begin{array}{c}.002 \\
(0.04)\end{array}$ & $\begin{array}{l}-.025 \\
(0.33)\end{array}$ & $\begin{array}{c}-.014 \\
(0.18)\end{array}$ & $\begin{array}{c}.070 \\
(0.89)\end{array}$ & $\begin{array}{c}.006 \\
(0.07)\end{array}$ \\
\hline Years of education & $\begin{array}{c}.024 * * * \\
(7.46)\end{array}$ & $\begin{array}{c}.022^{* * * *} * \\
(6.45)\end{array}$ & $\begin{array}{c}.018 * * * \\
(5.24)\end{array}$ & $\begin{array}{c}.017 * * * \\
(4.77)\end{array}$ & $\begin{array}{c}.027 * * * \\
(7.80)\end{array}$ & $\begin{array}{c}.024 * * * \\
(7.01)\end{array}$ & $\begin{array}{c}.016^{* * * *} \\
(4.60)\end{array}$ & $\begin{array}{c}.016^{* * * *} \\
(4.48)\end{array}$ \\
\hline Number of children & $\begin{array}{c}.019 \\
(1.59)\end{array}$ & $\begin{array}{c}.016 \\
(1.31)\end{array}$ & $\begin{array}{l}-.010 \\
(0.78)\end{array}$ & $\begin{array}{c}-.009 \\
(0.80)\end{array}$ & $\begin{array}{c}.057 * * * \\
(4.26)\end{array}$ & $\begin{array}{c}.053 * * * \\
(3.92)\end{array}$ & $\begin{array}{l}.028 * * \\
(2.09)\end{array}$ & $\begin{array}{l}.028^{*} \\
(1.94)\end{array}$ \\
\hline In good health & & $\begin{array}{l}.418 * * * \\
(17.08)\end{array}$ & $\begin{array}{l}.331 * * * \\
(13.22)\end{array}$ & $\begin{array}{l}.330 * * * \\
(13.18)\end{array}$ & & $\begin{array}{l}.496 * * * \\
(19.64)\end{array}$ & $\begin{array}{l}.407 * * * \\
(15.82)\end{array}$ & $\begin{array}{l}.409 * * * \\
(15.38)\end{array}$ \\
\hline Agricultural hukou & & $\begin{array}{c}.013 \\
(0.39)\end{array}$ & $\begin{array}{l}-.026 \\
(0.76)\end{array}$ & $\begin{array}{l}-.027 \\
(0.81)\end{array}$ & & $\begin{array}{c}.026 \\
(0.56)\end{array}$ & $\begin{array}{l}-.008 \\
(0.18)\end{array}$ & $\begin{array}{c}.017 \\
(0.36)\end{array}$ \\
\hline \multicolumn{9}{|l|}{ Employment Status } \\
\hline In labour force but unemployed & & $\begin{array}{l}-.089^{*} \\
(1.74)\end{array}$ & $\begin{array}{l}-.058 \\
(1.11)\end{array}$ & $\begin{array}{l}-.069 \\
(1.34)\end{array}$ & & $\begin{array}{c}-.208 * * * \\
(5.59)\end{array}$ & $\begin{array}{c}-.095^{* *} \\
(2.50)\end{array}$ & $\begin{array}{c}-.096^{* * *} \\
(2.46)\end{array}$ \\
\hline Not in labour force & & $\begin{array}{l}-.052^{*} \\
(1.79)\end{array}$ & $\begin{array}{l}-.029 \\
(1.00)\end{array}$ & $\begin{array}{l}-.020 \\
(0.68)\end{array}$ & & $\begin{array}{c}.024 \\
(0.65)\end{array}$ & $\begin{array}{c}.077 * * \\
(2.09)\end{array}$ & $\begin{array}{l}.087 * * \\
(2.27)\end{array}$ \\
\hline \multicolumn{9}{|l|}{ Household Characteristics } \\
\hline Household income pc (in Yuan) & $\begin{array}{l}.189 * * * \\
(15.40)\end{array}$ & $\begin{array}{l}.171 * * * \\
(13.79)\end{array}$ & $\begin{array}{c}.055^{* * * *} \\
(4.12)\end{array}$ & $\begin{array}{c}.046^{* * *} \\
(3.34)\end{array}$ & $\begin{array}{l}323 * * * \\
(21.76)\end{array}$ & $\begin{array}{l}.297 * * * \\
(19.66)\end{array}$ & $\begin{array}{c}.144 * * * \\
(8.90)\end{array}$ & $\begin{array}{c}.137 * * * \\
(8.15)\end{array}$ \\
\hline House area (in sq. metre) & & & & $\begin{array}{c}.000 * * * \\
(3.94)\end{array}$ & & & & $\begin{array}{c}.001 * * * \\
(3.46)\end{array}$ \\
\hline Family property & & & & $\begin{array}{l}.037^{*} \\
(1.72)\end{array}$ & & & & \\
\hline Family car & & & & $\begin{array}{c}.136 * * * \\
(3.28)\end{array}$ & & & & $\begin{array}{c}.071 \\
(0.86)\end{array}$ \\
\hline Rural & $\begin{array}{c}.012 \\
(0.43)\end{array}$ & $\begin{array}{l}-.008 \\
(0.25)\end{array}$ & $\begin{array}{c}-.059 * \\
(1.78)\end{array}$ & $\begin{array}{c}-.068 * * \\
(2.04)\end{array}$ & $\begin{array}{c}.271 * * * \\
(8.79)\end{array}$ & $\begin{array}{c}.176^{* * * *} \\
(3.66)\end{array}$ & $\begin{array}{c}-.089 * \\
(1.81)\end{array}$ & $\begin{array}{c}-.143 * * * \\
(2.75)\end{array}$ \\
\hline \multicolumn{9}{|l|}{ Comparison Variable } \\
\hline Equal to city average & & & $\begin{array}{c}-.243 * * * \\
(5.82)\end{array}$ & $\begin{array}{c}-.218 * * * \\
(5.14)\end{array}$ & & & $\begin{array}{c}-.256^{* * * *} \\
(5.50)\end{array}$ & $\begin{array}{c}-.258 * * * \\
(5.39)\end{array}$ \\
\hline Below city average & & & $\begin{array}{c}-.626^{* * *} * \\
(13.82)\end{array}$ & $\begin{array}{c}-.591 * * * \\
(12.73)\end{array}$ & & & $\begin{array}{c}-.472 * * * \\
(9.53)\end{array}$ & $\begin{array}{c}-.472 * * * \\
(9.18)\end{array}$ \\
\hline Far below city average & & & $\begin{array}{c}-1.059 * * * \\
(17.68)\end{array}$ & $\begin{array}{c}-1.028 * * * \\
(16.87)\end{array}$ & & & $\begin{array}{c}-.809 * * * \\
(14.85)\end{array}$ & $\begin{array}{c}-.793 * * * \\
(13.96)\end{array}$ \\
\hline Personal economic position: & & & & & & & & \\
\hline Better than last 10 years & & & $\begin{array}{c}.133^{* * * *} \\
(5.13)\end{array}$ & $\begin{array}{c}.129 * * * \\
(4.94)\end{array}$ & & & $\begin{array}{l}.452 * * * \\
(16.78)\end{array}$ & $\begin{array}{l}.440 * * * \\
(15.77)\end{array}$ \\
\hline Worse than last 10 years & & & $\begin{array}{c}-.223 * * * \\
(6.35)\end{array}$ & $\begin{array}{c}-.225 * * * \\
(6.35)\end{array}$ & & & $\begin{array}{c}-.319 * * * \\
(9.76)\end{array}$ & $\begin{array}{c}-.336^{* * * *} \\
(9.91)\end{array}$ \\
\hline Personal economic level: & & & & & & & & \\
\hline Expect increase 10 years later & & & $\begin{array}{c}.084 * * * \\
(3.22)\end{array}$ & $\begin{array}{c}.088 * * * \\
(3.33)\end{array}$ & & & & \\
\hline Expect decrease 10 years later & & & $\begin{array}{c}-.076 \\
(1.49) \\
\end{array}$ & $\begin{array}{c}-.075 \\
(1.48) \\
\end{array}$ & & & & \\
\hline $\mathbf{N}$ & 10235 & 10235 & 10235 & 10097 & 9674 & 9674 & 9674 & 9061 \\
\hline $\mathbf{C h i}^{2}$ & 1210.92 & 1516.48 & 2239.44 & 2268.14 & 1444.14 & 1868.87 & 2954.15 & 2766.65 \\
\hline Pseudo $\mathbf{R}^{2}$ & 0.05 & 0.06 & 0.09 & 0.09 & 0.06 & 0.08 & 0.13 & 0.13 \\
\hline
\end{tabular}

Notes: 1. Dependent variable is happiness score which varies between 1 (being very unhappy) and 5

(being very happy). 2.*,** and *** indicate significance at the $10 \%, 5 \%$ and $1 \%$ levels respectively.

3. For employment variables, the reference category is 'in labour force and employed'; for "family economic position", the reference category is 'family economic position: above city average'; for "personal economic position", the reference category is "Personal economic position: same as last 10 years'; for "personal economic level", the reference category is 'Personal economic level: no change 10 years later'. 4. All regressions include a full set of province dummies. 5: Data is from the Chinese General Social Survey (CGSS). 
Age effects are estimated via a quadratic form. In all cases there is a general U-shaped pattern between age and happiness that is consistent with the international literature (e.g. see Helliwell, 2006). ${ }^{29}$ Consistent with other Asian country studies (e.g. Tsou and Liu, 2001), marital status also influences happiness. This can be attributed to the fact that compared with the unmarried, married people can enjoy a family life and thus they have higher happiness scores. Happiness is also higher for the more educated which is consistent with the existing literature (see Blanchflower, 2008; Clark and Senik, 2011).

Turning to the number of children, there is a positive and significant relationship with happiness in the 2005 data, but this relationship is insignificant in 2010 (and it has a larger impact on females than on males as shown in Table 6). This is somewhat puzzling given that happiness is expected to be lower in larger families since income has to be shared with more members (Van Praag and Frijters, 1999). A positive correlation, however, may arise if there is unmet demand for children, particularly boys, given the "One Child Policy" (henceforth OCP) restriction on fertility. Therefore we carried out two additional tests (results not shown). First, we repeated the analysis using gender-wise data on the total number of children. The "number of sons" is found to be a positive correlate of happiness though significant only in the 2005 data. The "number of daughters" is never significant. This is consistent with "son preference" in Chinese society. Second, the OCP may have led to happiness loss that in turn cancels out the happiness gain from a smaller family size because of increased per capita household budget. This may explain why number of children is insignificant (in the 2010 data) or even positive (in the 2005 data). ${ }^{30}$ Therefore, in an alternative specification, we additionally controlled for OCP cohort membership with and without controlling for the number of children in the happiness regression model. We found clear evidence of a negative and significant OCP cohort effect.

However a particularly interesting finding is that women systematically report being happier than men in China. This result compares favorably with evidence from high income countries. ${ }^{31}$ The observed happiness gender gap is puzzling given that women are generally disadvantaged in the labour market relative to men and is widely referred to as the paradox of the contented female worker (Crosby, 1982).

Among other things, we find that ethnicity matters for happiness. Members of the minority communities are significantly happier. However this effect prevails only in the parsimonious specification (models 1 and 2) in the 2010 data. Controlling for comparison income returns an insignificant coefficient on the minority dummy. This pattern is stronger in the CGSS data for 2005 where a minority dummy always enters

\footnotetext{
${ }^{29}$ The pattern is less pronounced in the case of developed countries. Using panel data from Germany, the UK and Australia, Frijters and Beatton (2012) report a weaker U-shaped relationship for the 20-60 age range.

${ }^{30}$ Individuals who reached the official marriage age (20 for female, 22 for male) on/after the introduction of OCP are defined as members of the OCP cohort. In the CGSS data, the non-OCP cohort (defined as women (men) older than 20(22) in 1978) does have more babies than the OCP cohort.

${ }^{31}$ Clark and Senik (2011) report lower levels of happiness among men compared to women in Europe. A similar gender gap was also noted in the US during the 1970s. However Stevenson and Wolfers (2009) report declining subjective well-being among US women, both absolutely and relative to men, even though the lives of women in the United States have improved over the past three decades in terms of material well-being.
} 
the happiness function as a positive and significant determinant irrespective of the specification of the underlying regression model. This can be attributed to the fact that there are positive lifestyles and greater inherent capacities for happiness amongst ethnic minority Chinese, much of which is derived from personal relationships instead of materialism (Knight, Shi and Chang, 2014). Overall the results indicate that despite growing economic inequality, social development in China remains reasonably inclusive so that even after controlling for an absolute income gap between minority and majority groups, the former are happier than the latter. When the income gap is fully controlled for in the 2010 data (i.e. model 4 in Table 5), the minority dummy becomes insignificant so that the minority group is at least as happy as the Han group.

Our main correlate of interest however is per capita household income. Column 1 in Table 5 confirms that higher incomes represent a gain in the happiness of individuals. In looking at the correlation between income and happiness, it is possible that income is standing in for something else, such as relative income and income relative to past income, or for other variables correlated with income such as economic shock, agricultural hukou and poor health status. Therefore, it is unsurprising that the size of the income coefficient is significantly reduced when relative economic position is controlled for in our model (i.e. when moving from model 1 to model 3). ${ }^{32}$

Both health and unemployment status have a significant coefficient in model 2 while hukou type doesn't matter. But their inclusion doesn't cancel the absolute income effect. Models 2-4 include a measure of health, hukou type and unemployment status. The coefficient on the income variable falls significantly only in column 3 where the non-economic variables - measures of relative and aspiration incomes - enter the happiness equations with large coefficients. Perceived family economic position below city average lowers wellbeing. This is consistent with Knight and Gunatilaka (2012) who note that subjective well-being is raised by actual income but lowered by aspiration income. Expected improvement (decline) in personal economic position in the next 10 years positively and significantly (negative and insignificant) affected well-being which is consistent with Tao and Chiu (2009) who found a positive and significant role for upward comparisons in China while the role of downward comparisons is insignificant. ${ }^{33}$ This finding is also similar to that of Frijters, Liu and Meng (2012) and Liu and Shang (2012) both of which used data from Chinese Household Income Project $2002^{34}$. However even after controlling for relative and aspiration income effects, the influence of absolute income persists in Table 5. This implies that the estimated income-happiness relationship in the CGSS data is not simply offset by the negative influence of aspiration income on subjective well-being. In column 4, we add three measures of basic needs constructed using information on

\footnotetext{
${ }^{32}$ Using cross-sectional data from the first two rounds of the European Social Survey, Caporale et al (2009) find similar evidence - the positive and statistically significant relationship between absolute income and happiness is weakened by a reference group effect. Using data from the German Socioeconomic Panel covering the period 1992-1997, Ferrer-i-Carbonell (2005) found increases in family income accompanied by identical increases in the reference group's income did not affect well-being significantly.

${ }^{33}$ This also supports the view that social comparisons are not symmetric -- people tend to make upward comparisons more and ignore downward comparisons (Frank, 1985).

${ }^{34}$ In addition, Liu and Shang (2012) confirmed that the positive relationship between expected future income and happiness to be causal; compared to 2SLS estimates, OLS tended to understate the positive relationship between income expectations and happiness.
} 
conditions of the house and car ownership. ${ }^{35}$ This however doesn't explain the observed influence of absolute income as the coefficient size on the income variable doesn't change significantly between columns 3 and 4 .

It is noteworthy that our results show a clear negative effect of unemployment on happiness. In the 2010 data, the effect works through the income channel so that controlling for income, the unemployment variable becomes insignificant (see Table 5, columns 2 vs. 4). ${ }^{36}$ However, further analysis reveals a direct effect, independent of income. When the analysis is restricted to working age (16-55 for female and 16-60 for male) individuals only, the unemployment effect is negative and significant in both rounds of the CGSS data, and in all specifications (i.e. independent of controls for income effects). ${ }^{37}$ These findings are consistent with the view that China's transition to a market economy eroded much happiness by creating labour market uncertainties (Easterlin, 2012). ${ }^{38}$

\subsection{Sub-sample analysis}

Results presented in Table 5 highlight two puzzles. First, whilst there is a clear location disadvantage in the raw data on happiness scores (i.e. urban residents are happier), this is not evident in the regression analysis. The coefficient on the rural dummy is insignificant in models 1 and 2 in the 2010 data. Second, there is a clear gender advantage in the estimated happiness function (i.e. women are significantly happier than men) even though in the raw happiness scores, no such gap is present.

Much of the inequality in China is a rural-urban phenomenon. Moreover, rural location can proxy for isolation from growth centres and lower subjective assessments of well-being. ${ }^{39}$ If inequality affects happiness more in urban areas, its impact in the overall sample may be less pronounced. Equally there may be a gender-differentiated response to income and relative incomes. In addition, having wealthier neighbors lowers reported happiness even after controlling for own income. But this may affect men and urban residents more than women and rural residents respectively. Therefore we report estimates of happiness function separately for rural and urban sub-samples. Similar estimates are reported by gender in Table 6.

\footnotetext{
${ }^{35}$ For a similar approach, see Kingdon and Knight (2006).

${ }^{36}$ However, the effect is always significant in the 2005 round.

${ }^{37}$ Full results are not reported, but available from the authors upon request. We also experimented with alternative specification of "joblessness" by following Oshio, Nozaki and Kobayashi (2013), where "employed" is used as the reference group in the regression model against 3 included categories: (a) unemployed, (b) retired/at home, and (c) others - not in labor force. However this did not change our findings.

${ }^{38}$ According to Guriev and Zhuravskaya (2009), market transition in the post-communist world brings unhappiness for a number of other reasons such as deterioration of public goods, growing income inequality, increased uncertainty and changes in aspiration levels. Others point out that the decline in happiness is explained by corruption and poor government performance (Djankov, Nikolova and Zilinsky, in Press).

${ }^{39}$ For developing country evidence on isolation and happiness, see Fafchamps and Shilpi (2009).
} 
Table 6: Ordered Probit Estimates of the Determinants of Well-being in China by Location and Gender, 2005-2010

\begin{tabular}{|c|c|c|c|c|c|c|c|c|}
\hline \multirow{3}{*}{$\underline{\text { Personal Characteristics }}$} & \multicolumn{4}{|c|}{2010} & \multicolumn{4}{|c|}{2005} \\
\hline & \multirow{2}{*}{ Urban } & \multirow{2}{*}{ Rural } & \multirow[t]{2}{*}{ Female } & \multirow[t]{2}{*}{ Male } & \multirow[t]{2}{*}{ Urban } & \multirow[t]{2}{*}{ Rural } & \multirow[t]{2}{*}{ Female } & \multirow[t]{2}{*}{ Male } \\
\hline & & & & & & & & \\
\hline Age & $\begin{array}{l}-.045^{* * *} * \\
(7.00)\end{array}$ & $\begin{array}{l}-.031 * * * \\
(4.00)\end{array}$ & $\begin{array}{l}-.041 * * * \\
(5.91)\end{array}$ & $\begin{array}{l}-.036^{* * *} * \\
(5.00)\end{array}$ & $\begin{array}{l}-.049 * * * \\
(6.57)\end{array}$ & $\begin{array}{l}-.047 * * * \\
(5.19)\end{array}$ & $\begin{array}{l}-.045 * * * \\
(5.54)\end{array}$ & $\begin{array}{l}-.047 * * * \\
(5.74)\end{array}$ \\
\hline Age square/100 & $\begin{array}{l}.056^{* * * *} \\
(8.55)\end{array}$ & $\begin{array}{l}.044 * * * \\
(5.58)\end{array}$ & $\begin{array}{l}.052 * * * \\
(7.32)\end{array}$ & $\begin{array}{l}.048 * * * \\
(6.65)\end{array}$ & $\begin{array}{l}.048 * * * \\
(6.38)\end{array}$ & $\begin{array}{l}.054 * * * \\
(5.77)\end{array}$ & $\begin{array}{l}.048 * * * \\
(5.80)\end{array}$ & $\begin{array}{l}.049 * * * \\
(5.82)\end{array}$ \\
\hline Female & $\begin{array}{l}.140 * * * \\
(4.51)\end{array}$ & $\begin{array}{l}.087 * * \\
(2.23)\end{array}$ & & & $\begin{array}{l}.043 \\
(1.32)\end{array}$ & $\begin{array}{l}.044 \\
(1.08)\end{array}$ & & \\
\hline Minority & $\begin{array}{l}.004 \\
(0.06)\end{array}$ & $\begin{array}{l}.039 \\
(0.56)\end{array}$ & $\begin{array}{l}.081 \\
(1.24)\end{array}$ & $\begin{array}{l}.010 \\
(0.14)\end{array}$ & $\begin{array}{l}.084 \\
(0.98)\end{array}$ & $\begin{array}{l}.188^{* * *} \\
(2.40)\end{array}$ & $\begin{array}{l}.094 \\
(1.20)\end{array}$ & $\begin{array}{l}.223 * * * \\
(2.73)\end{array}$ \\
\hline \multicolumn{9}{|l|}{ Marital status } \\
\hline Married & $\begin{array}{l}.402 * * * \\
(6.25)\end{array}$ & $\begin{array}{l}.138 \\
(1.51)\end{array}$ & $\begin{array}{l}.226 * * * \\
(2.86)\end{array}$ & $\begin{array}{l}.358 * * * \\
(5.15)\end{array}$ & $\begin{array}{l}.463 * * * \\
(6.74)\end{array}$ & $\begin{array}{l}.544 * * * \\
(5.25)\end{array}$ & $\begin{array}{l}.398 * * * \\
(4.61)\end{array}$ & $\begin{array}{l}.483 * * * \\
(6.60)\end{array}$ \\
\hline Divorced & $\begin{array}{l}-.242^{* *} \\
(2.28)\end{array}$ & $\begin{array}{l}-.080 \\
(0.45)\end{array}$ & $\begin{array}{l}-.386 * * * \\
(2.95)\end{array}$ & $\begin{array}{l}-.131 \\
(1.04)\end{array}$ & $\begin{array}{l}-.271^{* *} \\
(2.12)\end{array}$ & $\begin{array}{l}-.087 \\
(0.32)\end{array}$ & $\begin{array}{l}-.379 * * \\
(2.17)\end{array}$ & $\begin{array}{l}-.190 \\
(1.27)\end{array}$ \\
\hline Widowed & $\begin{array}{l}.090 \\
(1.01)\end{array}$ & $\begin{array}{l}-.182 \\
(1.60)\end{array}$ & $\begin{array}{l}-.079 \\
(0.82)\end{array}$ & $\begin{array}{l}.029 \\
(0.28)\end{array}$ & $\begin{array}{l}.133 \\
(1.28)\end{array}$ & $\begin{array}{l}-.119 \\
(0.84)\end{array}$ & $\begin{array}{l}.114 \\
(0.99)\end{array}$ & $\begin{array}{l}-.246^{*} \\
(1.95)\end{array}$ \\
\hline Years of education & $\begin{array}{l}.013 * * * \\
(2.77)\end{array}$ & $\begin{array}{l}.025^{* * * *} \\
(4.31)\end{array}$ & $\begin{array}{l}.016^{* * * *} \\
(3.38)\end{array}$ & $\begin{array}{l}.016^{* * * *} \\
(2.91)\end{array}$ & $\begin{array}{l}.014 * * * \\
(2.91)\end{array}$ & $\begin{array}{l}.019 * * * \\
(3.20)\end{array}$ & $\begin{array}{l}.018 * * * \\
(3.54)\end{array}$ & $\begin{array}{l}.014 * * * \\
(2.64)\end{array}$ \\
\hline Number of children & $\begin{array}{l}-.015 \\
(0.84)\end{array}$ & $\begin{array}{l}.002 \\
(0.14)\end{array}$ & $\begin{array}{l}-.012 \\
(0.67)\end{array}$ & $\begin{array}{l}-.008 \\
(0.43)\end{array}$ & $\begin{array}{l}.035 \\
(1.65)\end{array}$ & $\begin{array}{l}.016 \\
(0.81)\end{array}$ & $\begin{array}{l}.015 \\
(0.75)\end{array}$ & $\begin{array}{l}.047 * * \\
(2.31)\end{array}$ \\
\hline In good health & $\begin{array}{l}.334 * * * \\
(10.23)\end{array}$ & $\begin{array}{l}.310^{* * * *} \\
(7.86)\end{array}$ & $\begin{array}{l}.342 * * * \\
(9.72)\end{array}$ & $\begin{array}{l}.313 * * * \\
(8.67)\end{array}$ & $\begin{array}{l}.419 * * * \\
(11.98)\end{array}$ & $\begin{array}{l}.379 * * * \\
(9.01)\end{array}$ & $\begin{array}{l}.381 * * * \\
(10.34)\end{array}$ & $\begin{array}{l}.455^{* * * *} \\
(11.70)\end{array}$ \\
\hline Agricultural hukou & $\begin{array}{l}-.046 \\
(1.17)\end{array}$ & $\begin{array}{l}.051 \\
(0.64)\end{array}$ & $\begin{array}{l}-.017 \\
(0.36)\end{array}$ & $\begin{array}{l}-.045 \\
(0.90)\end{array}$ & $\begin{array}{l}.063 \\
(1.01)\end{array}$ & $\begin{array}{l}-.061 \\
(0.67)\end{array}$ & $\begin{array}{l}.042 \\
(0.62)\end{array}$ & $\begin{array}{l}-.013 \\
(0.18)\end{array}$ \\
\hline Employment Status & & & & & & & & \\
\hline In labour force but unemployed & $\begin{array}{l}-.058 \\
(0.91)\end{array}$ & $\begin{array}{l}-.147 \\
(1.60)\end{array}$ & $\begin{array}{l}.019 \\
(0.24)\end{array}$ & $\begin{array}{l}-.137 * \\
(1.94)\end{array}$ & $\begin{array}{l}-.103 * * \\
(2.38)\end{array}$ & $\begin{array}{l}-.082 \\
(0.72)\end{array}$ & $\begin{array}{l}-.048 \\
(0.88)\end{array}$ & $\begin{array}{l}-.159 * * * \\
(2.76)\end{array}$ \\
\hline Not in labour force & $\begin{array}{l}-.045 \\
(1.16)\end{array}$ & $\begin{array}{l}.026 \\
(0.54)\end{array}$ & $\begin{array}{l}-.005 \\
(0.13)\end{array}$ & $\begin{array}{l}-.044 \\
(0.86)\end{array}$ & $\begin{array}{l}.122 * * * \\
(2.72)\end{array}$ & $\begin{array}{l}.026 \\
(0.24)\end{array}$ & $\begin{array}{l}.092^{*} \\
(1.78)\end{array}$ & $\begin{array}{l}.095 \\
(1.59)\end{array}$ \\
\hline \multicolumn{9}{|l|}{ Household Characteristics } \\
\hline Household income pc (in Yuan) & $\begin{array}{l}.034^{*} \\
(1.81)\end{array}$ & $\begin{array}{l}.069 * * * \\
(3.37)\end{array}$ & $\begin{array}{l}.068^{* * * *} \\
(3.59)\end{array}$ & $\begin{array}{l}.025 \\
(1.23)\end{array}$ & $\begin{array}{l}.123 * * * \\
(5.54)\end{array}$ & $\begin{array}{l}.173^{* * * *} \\
(6.35)\end{array}$ & $\begin{array}{l}.159 * * * \\
(6.58)\end{array}$ & $\begin{array}{l}.128 * * * \\
(5.37)\end{array}$ \\
\hline House area (in sq. metre) & $\begin{array}{l}.000^{* * * *} \\
(2.96)\end{array}$ & $\begin{array}{l}.001 * * \\
(2.25)\end{array}$ & $\begin{array}{l}.001 * * * \\
(3.54)\end{array}$ & $\begin{array}{l}.000 * \\
(1.88)\end{array}$ & $\begin{array}{l}.001^{* * * *} \\
(2.84)\end{array}$ & $\begin{array}{l}.001^{*} \\
(1.90)\end{array}$ & $\begin{array}{l}.000 \\
(1.30)\end{array}$ & $\begin{array}{l}.001 * * * \\
(3.45)\end{array}$ \\
\hline Family property & $\begin{array}{l}.035 \\
(1.39)\end{array}$ & $\begin{array}{l}.068 \\
(1.64)\end{array}$ & $\begin{array}{l}.020 \\
(0.65)\end{array}$ & $\begin{array}{l}.058 * * \\
(1.96)\end{array}$ & & & & \\
\hline Family car & $\begin{array}{l}.137 * * * \\
(2.92)\end{array}$ & $\begin{array}{l}.180^{*} \\
(1.90)\end{array}$ & $\begin{array}{l}.135^{* *} \\
(2.24)\end{array}$ & $\begin{array}{l}.122 * * \\
(2.12)\end{array}$ & $\begin{array}{l}.122 \\
(1.31)\end{array}$ & $\begin{array}{l}-.130 \\
(0.70)\end{array}$ & $\begin{array}{l}-.029 \\
(0.26)\end{array}$ & $\begin{array}{l}.182 \\
(1.49)\end{array}$ \\
\hline Rural & & & $\begin{array}{l}-.073 \\
(1.57)\end{array}$ & $\begin{array}{l}-.059 \\
(1.21)\end{array}$ & & & $\begin{array}{l}-.130^{*} \\
(1.76)\end{array}$ & $\begin{array}{l}-.134 * \\
(1.80)\end{array}$ \\
\hline \multicolumn{9}{|l|}{ Comparison Variables } \\
\hline \multicolumn{9}{|l|}{ Family economic position: } \\
\hline Equal to city average & $\begin{array}{l}-.201 * * * \\
(3.82)\end{array}$ & $\begin{array}{l}-.283 * * * \\
(3.86)\end{array}$ & $\begin{array}{l}-.185^{* * * *} \\
(2.99)\end{array}$ & $\begin{array}{l}-.256^{* * * *} \\
(4.35)\end{array}$ & $\begin{array}{l}-.289 * * * \\
(4.22)\end{array}$ & $\begin{array}{l}-.243 * * * \\
(3.55)\end{array}$ & $\begin{array}{l}-.397 * * * \\
(5.86)\end{array}$ & $\begin{array}{l}-.112 \\
(1.63)\end{array}$ \\
\hline Below city average & $\begin{array}{l}-.575 * * * \\
(9.90)\end{array}$ & $\begin{array}{l}-.660 * * * \\
(8.38)\end{array}$ & $\begin{array}{l}-.562 * * * \\
(8.42)\end{array}$ & $\begin{array}{l}-.629 * * * \\
(9.64)\end{array}$ & $\begin{array}{l}-.511 * * * \\
(7.08)\end{array}$ & $\begin{array}{l}-.445 * * * \\
(5.88)\end{array}$ & $\begin{array}{l}-.587 * * * \\
(8.06)\end{array}$ & $\begin{array}{l}-.351 * * * \\
(4.79)\end{array}$ \\
\hline Far below city average & $\begin{array}{l}-.990 * * * \\
(12.34)\end{array}$ & $\begin{array}{l}-1.115^{* * *} \\
(11.41)\end{array}$ & $\begin{array}{l}-.929 * * * \\
(10.89)\end{array}$ & $\begin{array}{l}-1.156^{* * * *} \\
(13.07)\end{array}$ & $\begin{array}{l}-.866^{* * * *} \\
(10.86)\end{array}$ & $\begin{array}{l}-.711^{* * *} * \\
(8.50)\end{array}$ & $\begin{array}{l}-.970 * * * \\
(12.10)\end{array}$ & $\begin{array}{l}-.607^{* * *} \\
(7.47)\end{array}$ \\
\hline \multicolumn{9}{|l|}{ Personal economic position: } \\
\hline Better than last 10 years & $\begin{array}{l}.076^{* * *} \\
(2.24)\end{array}$ & $\begin{array}{l}.195 * * * \\
(4.69)\end{array}$ & $\begin{array}{l}.141^{* * * *} \\
(3.85)\end{array}$ & $\begin{array}{l}.112 * * * \\
(2.96)\end{array}$ & $\begin{array}{l}.355 * * * \\
(9.57)\end{array}$ & $\begin{array}{l}.556^{* * * *} \\
(12.74)\end{array}$ & $\begin{array}{l}.477 * * * \\
(12.21)\end{array}$ & $\begin{array}{l}.402 * * * \\
(10.01)\end{array}$ \\
\hline Worse than last 10 years & $\begin{array}{l}-.240 * * * \\
(5.59)\end{array}$ & $\begin{array}{l}-.218 * * * \\
(3.42)\end{array}$ & $\begin{array}{l}-.219 * * * \\
(4.37)\end{array}$ & $\begin{array}{l}-.235^{* * * *} \\
(4.66)\end{array}$ & $\begin{array}{l}-.336^{* * * *} \\
(8.06)\end{array}$ & $\begin{array}{l}-.312 * * * \\
(5.26)\end{array}$ & $\begin{array}{l}-.313 * * * \\
(6.61)\end{array}$ & $\begin{array}{l}-.365^{* * *} \\
(7.47)\end{array}$ \\
\hline \multicolumn{9}{|l|}{ Personal economic level: } \\
\hline Expect increase 10 years later & $\begin{array}{l}.098^{* * * *} \\
(2.89)\end{array}$ & $\begin{array}{l}.057 \\
(1.34)\end{array}$ & $\begin{array}{l}.032 \\
(0.88)\end{array}$ & $\begin{array}{l}.148^{* * * *} \\
(3.87)\end{array}$ & & & & \\
\hline Expect decrease 10 years later & $\begin{array}{l}-.035 \\
(0.55) \\
\end{array}$ & $\begin{array}{l}-.147 * \\
(1.70)\end{array}$ & $\begin{array}{l}-.099 \\
(1.38)\end{array}$ & $\begin{array}{l}-.044 \\
(0.59)\end{array}$ & & & & \\
\hline $\mathbf{N}$ & 6055 & 4042 & 5182 & 4915 & 5388 & 3673 & 4647 & 4414 \\
\hline $\mathrm{Chi}^{2}$ & 1339.92 & 958.38 & 1211.26 & 1127.60 & 1595.48 & 1212.38 & 1435.70 & 1399.72 \\
\hline Pseudo $\mathbf{R}^{2}$ & 0.09 & 0.09 & 0.09 & 0.09 & 0.12 & 0.14 & 0.13 & 0.13 \\
\hline
\end{tabular}

1. Dependent variable is happiness score which varies between 1 (being very unhappy) and 5 (being very happy). 2. *,** and $* * *$ indicate significance at the $10 \%, 5 \%$ and $1 \%$ levels respectively. 3. For employment variables, the reference category is 'in labour force and employed'; for "family economic position", the reference category is 'family economic position: above city average'; for "personal economic position", the reference category is 'Personal economic position: same as last 10 years'; for "personal economic level", the reference category is 'Personal economic level: no change 10 years 
later'. 4. All regressions include a full set of province dummies. 5: Data is from the Chinese General Social Survey (CGSS).

A number of findings are noteworthy. The absolute income effect is much larger across all sub-samples - rural, urban, men and women - in 2005 compared to 2010 data. But irrespective of which round of CGSS data we look at, income effect is bigger in rural areas. This is consistent with the fact of higher poverty in rural areas and hence greater importance of income in determining happiness. In 2010 data, only fifth and sixth comparison variables have larger impact in urban areas, while in 2005 data all the comparison variables have larger impact. Turning to gender-specific samples, income effect is much bigger among women compared to men for whom relative income is more important in 2010 data. This gender differentiated income effect may explain why women are happier when gender gap in income is accounted for.

We further explore how the importance of relative income highlighted in Table 5 varies with absolute income, by examining whether relative income affects subjective well-being differently among the poor and better-off households. To this end, households are separated into two groups: the bottom 25\% and top 25\% income quartiles. This also serves as an indirect test of the modified Easterlin hypothesis (Stevenson and Wolfers, 2013). Estimates of happiness function specific to the two sub-samples are reported in Table 7. Absolute income always exerts a significant, positive influence on happiness scores in the parsimonious model (i.e. model 1) among the poor. In 2010 data, for the richest quartile, absolute income is insignificant in models 1 and 2, suggesting that there is a threshold level above which income has no further effect on happiness. Differences in estimated well-being-income gradients between the poor and the rich lend support to the modified Easterlin hypothesis.

The absolute income effect remains high and significant only for the poorest households in 2010 data even when we consider much detailed regression specifications (i.e. models 2-3) which account for other factors such as relative income, income relative to past income, economic shock, poor health status, and province dummies. The influence of income relative to past income as well as others in the locality remains significant and negative for all income groups. Accounting for these additional factors reduces the coefficient on absolute income variable for poorer households in 2010 and 2005 data. But in both cases, the coefficient remains significant. However the coefficient on the income variable also remains significant in the detailed specification among the richest households in 2005 data though the coefficient size is much bigger in case of the bottom poorest households. This once again confirms the changing pattern of happiness in China where relative instead of absolute income matters most among the richest. ${ }^{40}$

\footnotetext{
40 These results are consistent with findings from the literature on the higher influence of relative income in high-income countries (Corazzini, Esposito and Majorano, 2012) and the significance of absolute income for both poor and better-off households in low income developing countries (Asadullah and Chaudhury, 2012). Using the 2001 Taiwan Social Change Survey, Tao and Chiu (2009) also find relative income to be more important than absolute income in explaining happiness.
} 
Table 7: Ordered Probit Estimates of the Determinants of Well-being in China by Income Groups, 2005-2010

\begin{tabular}{|c|c|c|c|c|c|c|c|c|c|c|c|c|}
\hline & \multicolumn{6}{|c|}{2010} & \multicolumn{6}{|c|}{2005} \\
\hline & \multicolumn{3}{|c|}{ Poorest Quartile } & \multicolumn{3}{|c|}{ Richest Quartile } & \multicolumn{3}{|c|}{ Poorest Quartile } & \multicolumn{3}{|c|}{ Richest Quartile } \\
\hline & (1) & (2) & (3) & (1) & (2) & (3) & (1) & (2) & (3) & (1) & (2) & (3) \\
\hline \multicolumn{13}{|l|}{ Personal Characteristics } \\
\hline Age & $\begin{array}{c}-.031 * * * \\
(3.12)\end{array}$ & $\begin{array}{c}-.022 * * \\
(2.20)\end{array}$ & $\begin{array}{c}-.023 * * \\
(2.30)\end{array}$ & $\begin{array}{c}-.051 * * * \\
(4.91)\end{array}$ & $\begin{array}{c}-.049 * * * \\
(4.72)\end{array}$ & $\begin{array}{c}-.053^{* * * *} \\
(5.03)\end{array}$ & $\begin{array}{c}-.037 * * * \\
(3.59)\end{array}$ & $\begin{array}{c}-.040 * * * * \\
(3.86)\end{array}$ & $\begin{array}{c}-.038 * * * \\
(3.46)\end{array}$ & $\begin{array}{c}-.045^{* * *} \\
(3.88)\end{array}$ & $\begin{array}{c}-.039 * * * \\
(3.35)\end{array}$ & $\begin{array}{c}-.039 * * * \\
(3.20)\end{array}$ \\
\hline Age square/100 & $\begin{array}{c}.042 * * * \\
(4.46)\end{array}$ & $\begin{array}{c}.034 * * * * \\
(3.60)\end{array}$ & $\begin{array}{l}.035 * * * \\
(3.64)\end{array}$ & $\begin{array}{c}.065^{* * * *} \\
(6.10)\end{array}$ & $\begin{array}{c}.065^{* * *} \\
(6.00)\end{array}$ & $\begin{array}{c}.070 * * * \\
(6.40)\end{array}$ & $\begin{array}{c}.044 * * * \\
(4.35)\end{array}$ & $\begin{array}{l}.047 * * * * \\
(4.51)\end{array}$ & $\begin{array}{c}.044 * * * \\
(4.05)\end{array}$ & $\begin{array}{c}.046^{* * * *} \\
(3.77)\end{array}$ & $\begin{array}{l}.040 * * * \\
(3.26)\end{array}$ & $\begin{array}{c}.040 * * * \\
(3.17)\end{array}$ \\
\hline Female & $\begin{array}{c}.057 \\
(1.17)\end{array}$ & $\begin{array}{c}.022 \\
(0.44)\end{array}$ & $\begin{array}{c}.033 \\
(0.68)\end{array}$ & $\begin{array}{l}.149^{* * * *} \\
(3.07)\end{array}$ & $\begin{array}{l}.161^{* * * *} \\
(3.28)\end{array}$ & $\begin{array}{l}.167 * * * * \\
(3.37)\end{array}$ & $\begin{array}{c}.071 \\
(1.51)\end{array}$ & $\begin{array}{c}.038 \\
(0.78)\end{array}$ & $\begin{array}{c}.063 \\
(1.22)\end{array}$ & $\begin{array}{l}.120 * * \\
(2.53)\end{array}$ & $\begin{array}{l}.093^{*} \\
(1.94)\end{array}$ & $\begin{array}{l}.085^{*} \\
(1.73)\end{array}$ \\
\hline Minority & $\begin{array}{l}.166^{*} \\
(1.92)\end{array}$ & $\begin{array}{c}.099 \\
(1.14)\end{array}$ & $\begin{array}{c}.074 \\
(0.84)\end{array}$ & $\begin{array}{c}.097 \\
(0.89)\end{array}$ & $\begin{array}{c}.096 \\
(0.87)\end{array}$ & $\begin{array}{c}.075 \\
(0.68)\end{array}$ & $\begin{array}{c}.329 * * * \\
(3.52)\end{array}$ & $\begin{array}{c}.271 * * * * \\
(2.85)\end{array}$ & $\begin{array}{l}.239 * * \\
(2.37)\end{array}$ & $\begin{array}{c}.064 \\
(0.51)\end{array}$ & $\begin{array}{c}.042 \\
(0.33)\end{array}$ & $\begin{array}{c}.098 \\
(0.76)\end{array}$ \\
\hline \multicolumn{13}{|l|}{ Marital status } \\
\hline Married & $\begin{array}{c}.334^{* * * *} \\
(3.14)\end{array}$ & $\begin{array}{l}.265^{* *} \\
(2.47)\end{array}$ & $\begin{array}{l}.248 * * \\
(2.26)\end{array}$ & $\begin{array}{c}.372^{* * * *} \\
(3.94)\end{array}$ & $\begin{array}{c}.370^{* * * *} \\
(3.89)\end{array}$ & $\begin{array}{c}.355^{* * * *} \\
(3.67)\end{array}$ & $\begin{array}{c}.634 * * * \\
(5.54)\end{array}$ & $\begin{array}{c}.633 * * * \\
(5.43)\end{array}$ & $\begin{array}{c}.574 * * * * \\
(4.60)\end{array}$ & $\begin{array}{c}.383^{* * * *} \\
(3.98)\end{array}$ & $\begin{array}{c}.409^{* * * *} \\
(4.21)\end{array}$ & $\begin{array}{c}.388^{* * *} \\
(3.89)\end{array}$ \\
\hline Divorced & $\begin{array}{c}-.316 * * \\
(2.09)\end{array}$ & $\begin{array}{l}-.274^{*} \\
(1.80)\end{array}$ & $\begin{array}{l}-.289^{*} \\
(1.86)\end{array}$ & $\begin{array}{l}-.110 \\
(0.49)\end{array}$ & $\begin{array}{l}-.114 \\
(0.50)\end{array}$ & $\begin{array}{l}-.108 \\
(0.47)\end{array}$ & $\begin{array}{l}-.058 \\
(0.29)\end{array}$ & $\begin{array}{c}.065 \\
(0.32)\end{array}$ & $\begin{array}{c}.040 \\
(0.19)\end{array}$ & $\begin{array}{c}-.539^{* * *} \\
(1.97)\end{array}$ & $\begin{array}{l}-.564 * * \\
(2.04)\end{array}$ & $\begin{array}{c}-.622 * * \\
(2.19)\end{array}$ \\
\hline Widowed & $\begin{array}{l}-.048 \\
(0.39)\end{array}$ & $\begin{array}{l}-.019 \\
(0.15)\end{array}$ & $\begin{array}{l}-.037 \\
(0.28)\end{array}$ & $\begin{array}{l}.037 \\
(0.22)\end{array}$ & $\begin{array}{c}.060 \\
(0.36)\end{array}$ & $\begin{array}{l}.020 \\
(0.12)\end{array}$ & $\begin{array}{l}.125 \\
(0.89)\end{array}$ & $\begin{array}{c}.227 \\
(1.59)\end{array}$ & $\begin{array}{l}.160 \\
(1.05)\end{array}$ & $\begin{array}{c}.173 \\
(0.93)\end{array}$ & $\begin{array}{l}.146 \\
(0.78)\end{array}$ & $\begin{array}{l}.127 \\
(0.66)\end{array}$ \\
\hline Years of education & $\begin{array}{c}.022 * * * \\
(3.22)\end{array}$ & $\begin{array}{c}.019 * * * \\
(2.77)\end{array}$ & $\begin{array}{c}.018 * * * \\
(2.60)\end{array}$ & $\begin{array}{c}.011 \\
(1.46)\end{array}$ & $\begin{array}{c}.005 \\
(0.71)\end{array}$ & $\begin{array}{c}.002 \\
(0.24)\end{array}$ & $\begin{array}{c}.034 * * * * \\
(5.03)\end{array}$ & $\begin{array}{c}.028^{* * * *} \\
(3.99)\end{array}$ & $\begin{array}{c}.030^{* * * *} \\
(4.04)\end{array}$ & $\begin{array}{l}.016^{* * *} \\
(2.17)\end{array}$ & $\begin{array}{c}.012 \\
(1.54)\end{array}$ & $\begin{array}{c}.011 \\
(1.42)\end{array}$ \\
\hline Number of children & $\begin{array}{c}.019 \\
(0.92)\end{array}$ & $\begin{array}{l}-.004 \\
(0.21)\end{array}$ & $\begin{array}{l}-.003 \\
(0.15)\end{array}$ & $\begin{array}{l}-.045 \\
(1.45)\end{array}$ & $\begin{array}{l}-.052^{*} \\
(1.66)\end{array}$ & $\begin{array}{c}-.065^{* *} \\
(2.06)\end{array}$ & $\begin{array}{c}.027 \\
(1.27)\end{array}$ & $\begin{array}{c}.014 \\
(0.64)\end{array}$ & $\begin{array}{c}.021 \\
(0.91)\end{array}$ & $\begin{array}{c}.027 \\
(0.75)\end{array}$ & $\begin{array}{c}.014 \\
(0.40)\end{array}$ & $\begin{array}{l}-.007 \\
(0.19)\end{array}$ \\
\hline In good health & $\begin{array}{c}.383^{* * * *} \\
(8.10)\end{array}$ & $\begin{array}{l}.277^{* * * *} \\
(5.76)\end{array}$ & $\begin{array}{l}.267 * * * * \\
(5.49)\end{array}$ & $\begin{array}{c}.372 * * * \\
(7.03)\end{array}$ & $\begin{array}{c}.336^{* * * *} \\
(6.29)\end{array}$ & $\begin{array}{c}.337 * * * * \\
(6.24)\end{array}$ & $\begin{array}{l}.533^{* * * *} \\
(11.35)\end{array}$ & $\begin{array}{c}.449 \text { **** } \\
(9.35)\end{array}$ & $\begin{array}{c}.444^{* * * *} \\
(8.68)\end{array}$ & $\begin{array}{c}.517 * * * \\
(9.53)\end{array}$ & $\begin{array}{c}.443 * * * \\
(8.03)\end{array}$ & $\begin{array}{c}.456^{* * * *} \\
(8.11)\end{array}$ \\
\hline Agricultural hukou & $\begin{array}{l}-.006 \\
(0.09)\end{array}$ & $\begin{array}{c}-.076 \\
(1.02)\end{array}$ & $\begin{array}{l}-.075 \\
(0.99)\end{array}$ & $\begin{array}{l}-.037 \\
(0.52)\end{array}$ & $\begin{array}{l}-.053 \\
(0.74)\end{array}$ & $\begin{array}{l}-.034 \\
(0.48)\end{array}$ & $\begin{array}{l}-.015 \\
(0.15)\end{array}$ & $\begin{array}{l}-.104 \\
(1.01)\end{array}$ & $\begin{array}{l}-.042 \\
(0.38)\end{array}$ & $\begin{array}{c}.079 \\
(0.78)\end{array}$ & $\begin{array}{c}.078 \\
(0.75)\end{array}$ & $\begin{array}{c}.098 \\
(0.92)\end{array}$ \\
\hline \multicolumn{13}{|l|}{ Employment Status } \\
\hline In labour force but unemployed & $\begin{array}{l}-.007 \\
(0.08)\end{array}$ & $\begin{array}{c}.019 \\
(0.21)\end{array}$ & $\begin{array}{l}-.022 \\
(0.23)\end{array}$ & $\begin{array}{l}-.308^{*} \\
(2.55)\end{array}$ & $\begin{array}{c}-.332 * * * \\
(2.73)\end{array}$ & $\begin{array}{c}-.327 * * * \\
(2.65)\end{array}$ & $\begin{array}{c}-.236^{* * *} \\
(2.37)\end{array}$ & $\begin{array}{l}-.097 \\
(0.95)\end{array}$ & $\begin{array}{l}-.089 \\
(0.83)\end{array}$ & $\begin{array}{c}-.229 * * * \\
(3.00)\end{array}$ & $\begin{array}{l}-.132 * \\
(1.71)\end{array}$ & $\begin{array}{l}-.129 \\
(1.63)\end{array}$ \\
\hline Not in labour force & $\begin{array}{l}-.096^{*} \\
(1.75)\end{array}$ & $\begin{array}{l}-.045 \\
(0.81)\end{array}$ & $\begin{array}{l}-.040 \\
(0.71)\end{array}$ & $\begin{array}{l}-.062 \\
(0.97)\end{array}$ & $\begin{array}{c}-.087 \\
(1.33)\end{array}$ & $\begin{array}{c}-.086 \\
(1.31)\end{array}$ & $\begin{array}{l}-.159 \\
(1.62)\end{array}$ & $\begin{array}{l}-.043 \\
(0.43)\end{array}$ & $\begin{array}{l}-.035 \\
(0.33)\end{array}$ & $\begin{array}{c}.097 \\
(1.39)\end{array}$ & $\begin{array}{l}.150 * * \\
(2.12)\end{array}$ & $\begin{array}{l}.154^{* * *} \\
(2.13)\end{array}$ \\
\hline \multicolumn{13}{|l|}{ Household Characteristics } \\
\hline Household income pc (in Yuan) & $\begin{array}{c}.146^{* * *} \\
(4.54)\end{array}$ & $\begin{array}{l}.059^{*} \\
(1.77)\end{array}$ & $\begin{array}{l}.062^{*} \\
(1.84)\end{array}$ & $\begin{array}{c}.018 \\
(0.54)\end{array}$ & $\begin{array}{c}-.043 \\
(1.27)\end{array}$ & $\begin{array}{c}-.077 * * \\
(2.18)\end{array}$ & $\begin{array}{c}.151^{* * * *} \\
(3.98)\end{array}$ & $\begin{array}{l}.068^{*} \\
(1.74)\end{array}$ & $\begin{array}{c}.054 \\
(1.29)\end{array}$ & $\begin{array}{c}.138^{* * * *} \\
(3.50)\end{array}$ & $\begin{array}{c}.058 \\
(1.42)\end{array}$ & $\begin{array}{c}.017 \\
(0.40)\end{array}$ \\
\hline House area (in sq. metre) & & & $\begin{array}{l}.001^{*} \\
(1.88)\end{array}$ & & & $\begin{array}{c}.000 \\
(1.57)\end{array}$ & & & $\begin{array}{c}.001 * * * \\
(2.73)\end{array}$ & & & $\begin{array}{l}-.001 \\
(1.16)\end{array}$ \\
\hline Family property & & & $\begin{array}{l}-.005 \\
(0.09)\end{array}$ & & & $\begin{array}{c}.033 \\
(0.98)\end{array}$ & & & & & & \\
\hline Family car & & & $\begin{array}{l}.211 \\
(1.07)\end{array}$ & & & $\begin{array}{l}.224 * * * * \\
(3.98)\end{array}$ & & & $\begin{array}{c}-.730 * * \\
(2.35)\end{array}$ & & & $\begin{array}{l}.187^{*} \\
(1.94)\end{array}$ \\
\hline
\end{tabular}




\begin{tabular}{|c|c|c|c|c|c|c|c|c|c|c|c|c|}
\hline Rural & $\begin{array}{c}.016 \\
(0.24)\end{array}$ & $\begin{array}{l}-.039 \\
(0.61)\end{array}$ & $\begin{array}{l}-.052 \\
(0.79)\end{array}$ & $\begin{array}{l}-.014 \\
(0.17)\end{array}$ & $\begin{array}{l}-.055 \\
(0.67)\end{array}$ & $\begin{array}{l}-.069 \\
(0.83)\end{array}$ & $\begin{array}{l}.111 \\
(1.07)\end{array}$ & $\begin{array}{l}-.086 \\
(0.81)\end{array}$ & $\begin{array}{l}-.167 \\
(1.48)\end{array}$ & $\begin{array}{l}.201^{*} \\
(1.79)\end{array}$ & $\begin{array}{l}-.011 \\
(0.10)\end{array}$ & $\begin{array}{l}-.027 \\
(0.22)\end{array}$ \\
\hline \multicolumn{13}{|l|}{ Comparison Variables } \\
\hline \multicolumn{13}{|l|}{ Family economic position: } \\
\hline Equal to city average & & $\begin{array}{l}-.188 \\
(1.20)\end{array}$ & $\begin{array}{l}-.182 \\
(1.16)\end{array}$ & & $\begin{array}{c}-.323 * * * \\
(5.37)\end{array}$ & $\begin{array}{c}-.302 * * * \\
(4.92)\end{array}$ & & $\begin{array}{l}-.017 \\
(0.13)\end{array}$ & $\begin{array}{l}-.015 \\
(0.11)\end{array}$ & & $\begin{array}{c}-.274 * * * \\
(3.68)\end{array}$ & $\begin{array}{c}-.291 * * * \\
(3.78)\end{array}$ \\
\hline Below city average & & $\begin{array}{c}-.597 * * * * \\
(3.83)\end{array}$ & $\begin{array}{l}-.586 * * * \\
(3.75)\end{array}$ & & $\begin{array}{c}-.569 * * * \\
(7.20)\end{array}$ & $\begin{array}{c}-.520^{* * * *} \\
(6.43)\end{array}$ & & $\begin{array}{l}-.254^{*} \\
(1.89)\end{array}$ & $\begin{array}{c}-.281 * * \\
(2.01)\end{array}$ & & $\begin{array}{c}-.487 * * * * \\
(5.75)\end{array}$ & $\begin{array}{c}-.516^{* * * *} \\
(5.85)\end{array}$ \\
\hline Far below city average & & $\begin{array}{c}-.972 * * * \\
(5.94)\end{array}$ & $\begin{array}{c}-.956^{* * *} \\
(5.82)\end{array}$ & & $\begin{array}{c}-.963 * * * \\
(5.12)\end{array}$ & $\begin{array}{c}-.907 * * * \\
(4.73)\end{array}$ & & $\begin{array}{l}-.600 * * * \\
(4.40)\end{array}$ & $\begin{array}{c}-.589 * * * \\
(4.15)\end{array}$ & & $\begin{array}{c}-.868 * * * \\
(7.66)\end{array}$ & $\begin{array}{l}-.905^{* * * *} \\
(7.56)\end{array}$ \\
\hline \multicolumn{13}{|l|}{ Personal economic position: } \\
\hline Better than last 10 years & & $\begin{array}{l}.212 * * * \\
(4.12)\end{array}$ & $\begin{array}{c}.215 * * * \\
(4.14)\end{array}$ & & $\begin{array}{l}-.012 \\
(0.22)\end{array}$ & $\begin{array}{l}-.024 \\
(0.45)\end{array}$ & & $\begin{array}{l}.558 * * * \\
(10.14)\end{array}$ & $\begin{array}{c}.535^{* * * *} \\
(9.10)\end{array}$ & & $\begin{array}{c}.313^{* * * *} \\
(5.97)\end{array}$ & $\begin{array}{c}.306^{* * * *} \\
(5.73)\end{array}$ \\
\hline Worse than last 10 years & & $\begin{array}{c}-.246 * * * \\
(3.69)\end{array}$ & $\begin{array}{l}-.250 * * * \\
(3.73)\end{array}$ & & $\begin{array}{c}-.208 * * * \\
(2.75)\end{array}$ & $\begin{array}{c}-214 * * * \\
(2.80)\end{array}$ & & $\begin{array}{c}-.427 * * * \\
(7.29)\end{array}$ & $\begin{array}{c}-.450 * * * \\
(7.24)\end{array}$ & & $\begin{array}{c}-.247 * * * \\
(3.23)\end{array}$ & $\begin{array}{c}-.270^{* * * *} \\
(3.49)\end{array}$ \\
\hline \multicolumn{13}{|l|}{ Personal economic level: } \\
\hline Expect increase 10 years later & & $\begin{array}{c}.067 \\
(1.34)\end{array}$ & $\begin{array}{c}.069 \\
(1.37)\end{array}$ & & $\begin{array}{l}.076 \\
(1.37)\end{array}$ & $\begin{array}{c}.088 \\
(1.58)\end{array}$ & & & & & & \\
\hline Expect decrease 10 years later & & $\begin{array}{l}-.025 \\
(0.24)\end{array}$ & $\begin{array}{l}-.028 \\
(0.26)\end{array}$ & & $\begin{array}{c}-.116 \\
(1.19)\end{array}$ & $\begin{array}{l}-.110 \\
(1.13)\end{array}$ & & & & & & \\
\hline $\mathbf{N}$ & 2523 & 2523 & 2479 & 2574 & 2574 & 2544 & 2577 & 2577 & 2279 & 2395 & 2395 & 2328 \\
\hline $\mathrm{Chi}^{2}$ & 397.29 & 643.16 & 638.76 & 257.39 & 344.73 & 362.49 & 474.33 & 874.96 & 781.68 & 283.29 & 456.77 & 459.18 \\
\hline Pseudo $\mathbf{R}^{2}$ & 0.05 & 0.09 & 0.09 & 0.04 & 0.06 & 0.07 & 0.07 & 0.14 & 0.14 & 0.05 & 0.08 & 0.09 \\
\hline
\end{tabular}

Notes: 1 . Dependent variable is happiness score which varies between 1 (being very unhappy) and 5 (being very happy). $2 . *, * *$ and $* * *$ indicate significance at the $10 \%, 5 \%$ and $1 \%$ levels respectively. 3 . For employment variables, the reference category is 'in labour force and employed'; for "family economic position", the reference category is

'family economic position: above city average'; for "personal economic position", the reference category is 'Personal economic position: same as last 10 years'; for "personal economic level”, the reference category is 'Personal economic level: no change 10 years later'. 4 . All regressions include a full set of province dummies. 5: Data is from the Chinese General Social Survey (CGSS). 
Table 8: Ordered Probit Estimates of the Determinants of Well-being in China (based on non-linear income specification), 2005-2010

\begin{tabular}{|c|c|c|c|c|}
\hline CGSS 2010 & (1) & (2) & (3) & (4) \\
\hline Household income pc, $2^{\text {nd }}$ quartile & $.141^{* * * *}$ & $\begin{array}{l}.123^{* * * *} \\
(4.41)\end{array}$ & $\begin{array}{l}.058^{* * *} \\
(2.05)\end{array}$ & $\begin{array}{l}.069 * * \\
(2.42)\end{array}$ \\
\hline Household income $\mathrm{pc}, 3^{\text {rd }}$ quartile & $\begin{array}{c}(5.08) \\
.247 * * * \\
(8.31)\end{array}$ & $\begin{array}{c}(4.41) \\
.205 * * * \\
(6.87)\end{array}$ & $\begin{array}{c}(2.0 \%) \\
.079 * * * \\
(2.59)\end{array}$ & $.091^{* * *}$ \\
\hline Household income pc, $4^{\text {th }}$ quartile & $\begin{array}{l}.391 * * * \\
(12.46)\end{array}$ & $\begin{array}{l}.348 * * * \\
(10.98)\end{array}$ & $\begin{array}{c}.122 * * * \\
(3.70)\end{array}$ & $\begin{array}{c}.113^{* * *} \\
(3.34)\end{array}$ \\
\hline $\begin{array}{l}\text { Control for age, gender, marital status, ethnicity, education } \\
\text { and number of children }\end{array}$ & Yes & Yes & Yes & Yes \\
\hline Control for health, employment status and hukou type & No & Yes & Yes & Yes \\
\hline Control for comparison variables & No & No & Yes & Yes \\
\hline Control for household assets & No & No & No & Yes \\
\hline Province dummies & Yes & Yes & Yes & Yes \\
\hline $\mathrm{N}$ & 11733 & 11733 & 11733 & 11510 \\
\hline $\mathrm{Chi}^{2}$ & 1299.38 & 1666.38 & 2574.69 & 2583.13 \\
\hline Pseudo $\mathrm{R}^{2}$ & 0.0461 & 0.0592 & 0.0914 & 0.0934 \\
\hline CGSS 2005 & (1) & (2) & (3) & (4) \\
\hline Household income pc, $2^{\text {nd }}$ quartile & $\begin{array}{l}.229 * * * \\
(7.49)\end{array}$ & $\begin{array}{c}.206^{* * *} \\
(6.68)\end{array}$ & $\begin{array}{c}.082 * * * \\
(2.61)\end{array}$ & $\begin{array}{c}.095^{* * *} \\
(2.86)\end{array}$ \\
\hline Household income pc, $3^{\text {rd }}$ quartile & $\begin{array}{l}.475 * * * \\
(14.22)\end{array}$ & $\begin{array}{l}.437 * * * \\
(12.98)\end{array}$ & $\begin{array}{c}.223 * * * \\
(6.41)\end{array}$ & $\begin{array}{c}.233 * * * \\
(6.39)\end{array}$ \\
\hline Household income pc, $4^{\text {th }}$ quartile & $\begin{array}{l}.755^{* * *} \\
(20.39)\end{array}$ & $\begin{array}{l}.701 * * * \\
(18.64)\end{array}$ & $\begin{array}{c}353 * * * \\
(8.90)\end{array}$ & $\begin{array}{c}.365^{* * *} \\
(8.77)\end{array}$ \\
\hline $\begin{array}{l}\text { Control for age, gender, martial status, ethnicity, education } \\
\text { and number of children }\end{array}$ & Yes & Yes & Yes & Yes \\
\hline Control for health, employment status and hukou type & No & Yes & Yes & Yes \\
\hline Control for comparison variables & No & No & Yes & Yes \\
\hline Control for household assets & No & No & No & Yes \\
\hline Province dummies & Yes & Yes & Yes & Yes \\
\hline $\mathrm{N}$ & 10361 & 10361 & 10361 & 9549 \\
\hline $\mathrm{Chi}^{2}$ & 1447.79 & 1933.78 & 3163.39 & 2929.14 \\
\hline Pseudo $\mathrm{R}^{2}$ & 0.06 & 0.08 & 0.13 & 0.13 \\
\hline
\end{tabular}

Notes: 1. Dependent variable is happiness score which varies between 1 (being very unhappy) and 5 (being very happy). 2.*,** and $* * *$ indicate significance at the $10 \%, 5 \%$ and $1 \%$ levels respectively.

3. For full specification of the regression model, see Table 5. 4: Data is from the Chinese General Social Survey (CGSS).

In order to formally explore the non-linearity in the impact of absolute income, we reproduce Table 5 where we replace the per capita income variable by three dummy variables corresponding to the top three income quartiles. Results are reported in Table 8. Irrespective of the regression model used, increase in household income leads to significant gain in happiness in CGSS 2010 data. The coefficient on the top income quartile dummy is twice that on the second in the parsimonious specification (model 1). Controlling for employment and health status and hukou type reduces size of the coefficients (model 2) and they still remain sizable even after controlling for comparison variables. Moreover, the monotonic relationship between income and happiness prevails across all models (1 through 4$)$. Gains in happiness across absolute income quartiles are much larger in CGSS 2005 compared to 2010 data. The coefficient on the top income quartile dummy is four times that on the second irrespective of the overall specification of 
the regression models. In other words, the happiness-income gradient for China was much steeper in 2005 data. With an increase in income between 2005 and 2010, the role of absolute income has become less pronounced in the happiness function. This is consistent with cross-country studies that report a flatter income-happiness relationship among countries that are richer (Deaton, 2008).

\subsection{Oaxaca decomposition analysis}

In this section, we revisit two puzzles we have highlighted earlier, related to gender and location as determinants of happiness in China. The urban-rural happiness gap has increased from 0.08 to 0.12 points between 2005 and 2010 (2.3\% and 3.2\% of 2005 and 2010 mean happiness figures respectively). In order to formally test whether the observed happiness gap by location in the raw data (see Table 1) is entirely explained by the superior characteristics endowment of urban residents over rural residents, we perform the Oaxaca decomposition analysis. The following equation is estimated $\overline{\mathrm{H}_{\text {Urban }}}-$ $\overline{\mathrm{H}_{\text {Rural }}}=\dot{\beta}_{\text {Urban }} *\left(\overline{X_{\text {Urban }}}-\overline{X_{\text {Rural }}}\right)+{\overline{X_{\text {Rural }}}} *\left(\dot{\beta}_{\text {Urban }}-\dot{\beta}_{\text {Rural }}\right)$ where

OLS regressions are used to estimate the underlying happiness functions. ${ }^{41}$ The results are reported in Table $9 .{ }^{42}$ In all cases, most of the happiness gap is explained by characteristic differences in the 2010 data. This explains why controlling for absolute income differences, there are no happiness differences between rural and urban residents in Table 5. Results are similar for the 2005 data. $^{43}$

Table 9: Oaxaca Decomposition of Rural-Urban Gap in Well-being, 2005-2010

\begin{tabular}{lcccc}
\hline CGSS 2010 & $\mathbf{( 1 )}$ & $\mathbf{( 2 )}$ & $\mathbf{( 3 )}$ & $\mathbf{( 4 )}$ \\
\cline { 2 - 5 } Explained variation & 0.133 & 0.116 & 0.0879 & 0.075 \\
(in \%) & $(109.92 \%)$ & $(95.86 \%)$ & $(72.64 \%)$ & $(60.48 \%)$ \\
Unexplained variation & -0.012 & 0.005 & 0.042 & 0.049 \\
\cline { 2 - 5 } Raw mean difference & 0.121 & 0.121 & 0.121 & 0.124 \\
$\mathbf{N}$ & 10235 & 10235 & 10235 & 10097 \\
\cline { 2 - 5 } & \multicolumn{4}{c}{$(3)$} \\
CGSS 2005 & $(1)$ & $(2)$ & $(4)$ \\
Explained variation & 0.259 & 0.191 & 0.026 & 0.011 \\
(in \%) & $(315.85)$ & $(232.92 \%)$ & $(31.71 \%)$ & $(13.92 \%)$ \\
Unexplained variation & -0.177 & -0.109 & 0.056 & 0.068 \\
\cline { 2 - 5 } Raw mean difference & 0.082 & 0.082 & 0.082 & 0.079 \\
$\mathbf{N}$ & 9674 & 9674 & 9674 & 9061 \\
\hline Control for age, gender, marital status, ethnicity, & Yes & Yes & Yes & Yes \\
education and number of children & \multicolumn{3}{c}{ Yes } & Yes \\
Control for health, employment status and hukou type & No & Yes & & \\
\hline
\end{tabular}

\footnotetext{
${ }^{41}$ Following Sinning et al (2008), we also implemented a non-linear decomposition analysis using ordered probit regressions. However, this approach failed in a couple of instances because of a convergence problem.

${ }^{42}$ Our conclusion does not change if we use coefficients from pooled regression or urban sub-sample regression.

${ }^{43}$ We also estimated an alternative specification where we included mean per capita income at the county level as an additional proxy of relative income (results not reported but available upon request). While the variable enters the happiness function with a positive and significant coefficient in the rural sub-sample, it neither cancelled the effect of absolute income and comparison income variables, nor changed the results of the Oaxaca decomposition analysis.
} 


\begin{tabular}{lcccc}
\hline Control for comparison variables & No & No & Yes & Yes \\
Control for household assets & No & No & No & Yes \\
Province dummies & Yes & Yes & Yes & Yes \\
\hline
\end{tabular}

Notes: 1. Dependent variable is happiness score which varies between 1 (being very unhappy) and 5 (being very happy). 2.*, ** and *** indicate significance at the $10 \%, 5 \%$ and $1 \%$ levels respectively.

3. For full-specification, see Table 5. 4. Pooled coefficient vector used as weights.

5. Data is from the Chinese General Social Survey (CGSS).

We can't directly apply the Oaxaca framework to explain the paradox of contented women since the gender happiness paradox is completely absent in Table 1 . What then explains the fact that the mean happiness of men and women in China (3.76 and 3.77 in 2010 and 3.42 and 3.41 in 2005 data respectively) remains unchanged over time and yet there is a statistically significant gender happiness gap in the conditional data? This is a puzzle given that women in our data are many times poorer than men when assessed in terms of total earnings, non-agricultural earnings as well as household income data. As seen from the Appendix, Table 2, the gender gap in income has increased in recent years e.g. the gender earnings gap increased from $28 \%$ to $45 \%$ between 2005 and 2010 . And yet the coefficient on female dummy has changed in the opposite direction and doubled in size over the same time period. This is explained as a combination of two gender-specific patterns. First, the influence of absolute income is larger among females while men no longer draw any satisfaction from their superior income - the coefficient on the income dummy is smaller in the male regression (see Table 7). ${ }^{44}$ Second, men are more concerned about comparison incomes than women. In Table 7, the coefficient on the variable "Expect increase 10 years later" is positive and significant for men, but insignificant for women. This implies that the potential gain from rising income among men vis-à-vis women has been offset by the gender-differentiated changes in comparison incomes.

\section{Conclusion}

Whether or not improvement in a country's macroeconomic conditions and the subsequent growth in private income impact its citizens' happiness is an old question in the economics literature. While for developing countries most researchers find that income matters for happiness, evidence on the importance of relative income remains mixed. There is also an ongoing debate on the magnitude of the income-happiness gradient and on happiness trends over time in China. Despite the fall in poverty and an unprecedented economic growth in recent decades, the unemployment rate has risen in China, accompanied by growing gender and rural-urban disparities. Consequently, the number of people who are relatively poor has not declined significantly as inequality persists (Chen 2015). In this context, we revisited the role of absolute and relative income as determinants of happiness in China with additional emphasis on gender and location.

Compared to earlier studies (e.g. Brockmann et al., 2009), we find that well-being in China appears to have risen in recent years, for all income and social groups, indicating a period of modest recovery in happiness, as also argued by Easterlin et al., (2012) and Easterlin (2012). Our estimates of the micro-determinants of well-being show that relative income matters for individual well-being: individuals who report their economic position

\footnotetext{
${ }^{44}$ An earlier study (Mishra and Smyth, 2014) found that the relationship between happiness and wages is stronger for males than it is for females in China. However this result is difficult to generalise, as the sample comprises 3390 urban respondents (from six Chinese cities) and that too from sectors such as heavy manufacturing and mining where women are likely to be under-represented.
} 
to be lower than others in the community and/or worse than that 10 years ago also report being less happy with life. However, overall, relative deprivation remains the dominant concern confirming that income poverty is not the main correlate of well-being in China, particularly beyond some level of income and/or basic needs. This finding is consistent with the modified-Easterlin hypothesis. Income aspirations increase with people's income as well as income of others in the community and this is one explanation for the declining importance of absolute income as a determinant of happiness. Among other factors, unemployment status systematically lowers happiness in China, particularly among men. This is consistent with evidence from the international literature on happiness (Clark and Oswald, 1994; Helliwell, 2003; Blanchflower, Bell, Montagnoli and Moro, 2014) as well as the experience of transition economies where job insecurity has been identified as a significant determinant of happiness loss (Namazie and Sanfey, 2001; Hayo, 2007; Selezneva, 2011; Rodriguez-Pose and Maslauskaite, 2012; Ivlevs, 2014).

Sub-sample estimates of the happiness function shed further light on the reasons for the weakening relationship between income and happiness. Economic growth in China benefited men disproportionately, increasing the gender gap in income. Yet the influence of absolute income on happiness is larger among women who are financially poorer and low paid. On the other hand, Chinese men draw little satisfaction from their higher absolute income and instead worry more about relative incomes. This also explains the absence of a gender gap in the raw data on happiness despite growing gender income inequality in China.

Lastly, it would be incorrect to conclude on the basis of our findings that China is becoming "happier" over time. The recent rise in happiness, as observed in CGSS 20052010 data, has a historical context - it is preceded by a decline in the 1990s even though China experienced a marked rise in consumption and income from a very low initial level since 1990. However, the level of happiness was much higher in 1990 because of state guaranteed jobs, low unemployment rate, and extensive social safety net provisions (Easterlin et al., 2012). This is similar to the experience of other economies in Central and Eastern Europe, which went through the transition from a planned economy to a market economy and experienced an initial decline in life satisfaction, but then recovered giving rise to a U-shaped pattern in happiness (Sanfey and Teksoz, 2007; Guriev and Zhuravskaya, 2009). ${ }^{45}$ In that sense, our analysis presents the most updated microeconometric estimate of the happiness function for a time period that coincides with the rising part of the aggregate U-shaped pattern in happiness in China. We have also added to the growing evidence on the importance of relative income and labour market uncertainties as correlates of well-being in transition countries. China's transition to a market economy has created new challenges following the dissolution of social safety net programs and the end of full employment. Therefore, policies that tackle unemployment and narrow rural-urban and gender inequalities will play an important role in sustaining improvements in well-being in the near future.

\footnotetext{
45 In general, the post-communist countries experienced less happiness in the early stage of transition toward the market economy (Tsai, 2009).
} 


\section{Reference}

Ambrey, C.L. and Fleming, C.M. (2014). The causal effect of income on life satisfaction and the implications for valuing non-market goods. Economics Letters, 123(2): 131-134.

Appleton, S., Knight, J., Song, L. and Xia, Q. (2009). The economics of Communist Party membership: The curious case of rising numbers and wage premium during China's transition. Journal of Development Studies, 45(2): 256-275.

Appleton, S. and Song, L. (2008). Life satisfaction in urban China: Components and determinants. World Development, 36(11): 2325-2340.

Asadullah, M. N. and Chaudhury, N. (2012). Subjective well-being and relative poverty in rural Bangladesh. Journal of Economic Psychology, 33(5): 940-950.

Benjamin, D., Brandt, L. and Giles, J. (2005). The evolution of income inequality in rural China. Economic Development and Cultural Change, 53(4): 769-824.

Blanchflower, D.G. (2008). International evidence on well-being. IZA Discussion Paper No. 3354. Institute for the Study of Labour, Bonn.

Blanchflower, D.G., and Oswald, A.J. (2008). Hypertension and happiness across nation. Journal of Health Economics, 27(2): 218-233.

Blanchflower, D. G., Bell, D. N., Montagnoli, A. and Moro, M. (2014). The happiness trade-off between unemployment and inflation. Journal of Money, Credit and Banking, 46(S2): 117-141.

Bollen, K.A. (1989). A new incremental fit index for general structural equation models. Sociological Methods and Research. 17(3):303-316.

Brockmann, H., Delhey, J., Welzel, C., and Yuan, H. (2009). The China puzzle: Falling happiness in a rising economy. Journal of Happiness Studies, 10(4): 387-405.

Cai, F., Du, Y. and Wang, M. (2013). Demystify the labour statistics in China. China Economic Journal, 6(2-3): 123-133.

Camfield, L. and Esposito, L. (2014). A cross-country analysis of perceived economic status and life satisfaction in high- and low-income countries. World Development, 59: 212-223.

Caporale, G. M., et al. (2009). Income and happiness across Europe: Do reference values matter?. Journal of Economic Psychology, 30(1): 42-51.

Carlsson, F., Gupta, G. and Johansson-Stenman, O. (2009). Keeping up with the vaishyas? Caste and relative standing in India. Oxford Economic Papers, 61(1): 52-73.

Chan, K.W. and Buckingham, W. (2008). Is China abolishing the hukou system?. The China Quarterly, 195(1): 582-606. 
Chen, Z. and Davey, G. (2008). Happiness and subjective well-being in mainland China. Journal of Happiness Studies, 9(4): 589-600.

Chen, X. (2015). Status concern and relative deprivation in China: measures, empirical evidence, and economic and policy implications. IZA Discussion Paper No. 9519.

Chyi, H. and Mao, S.Y. (2011). The determinants of happiness of China's elderly population. Journal of Happiness Studies. 13(1): 167-185.

Clark, A.E., Frijters, P. and Shields, M.A. (2008). Relative income, happiness, and utility: an explanation for the Easterlin Paradox and other puzzles. Journal of Economic Literature, 46(1): 95-144.

Clark, A.E. and Oswald, A.J. (1994). Unhappiness and unemployment. The Economic Journal, 104: 648-659.

Clark, A. and Senik, C. (2011). Will GDP growth increase happiness in developing countries. IZA Discussion Paper No. 5595. Institute for the Study of Labour, Bonn.

Corazzini, L., Esposito, L. and Majorano, F. (2012). Reign in hell or serve in heaven? A cross-country journey into the relative vs absolute perceptions of well-being. Journal of Economic Behavior and Organization, 81(3): 715-730.

Crosby, F.J. (1982). Relative deprivation and working women. New York: Oxford University Press.

Deaton, A. (2008). Income, health, and well-being around the world: evidence from the Gallup World Poll. Journal of Economic Perspectives, 22(2): 53-72.

Di Tella, R. and Haisken-De New, J. and MacCulloch, R. (2010). Happiness adaptation to income and to status in an individual panel. Journal of Economic Behavior and Organization, 76(3): 834-852.

Di Tella, R. and MacCulloch, R. (2006). Some uses of happiness data in economics. Journal of Economic Perspectives, 20(1): 25-46.

Djankov, Simeon, Elena Nikolova, and Jan Zilinsky. (In Press). The happiness gap in Eastern Europe. Journal of Comparative Economics.

Dolan, P. and Metcalfe, R. (2012). Measuring subjective well-being: recommendations on measures for use by national governments. Journal of Social Policy, 41(2). 409-427.

Easterlin, R. (2012). When growth outpaces happiness. The New York Times, Sept. 27.

Easterlin, R. A. (2013). Happiness, growth, and public policy. Economic Inquiry, 51(1): $1-15$.

Easterlin, R.A. and Angelescu, L. (2009). Happiness and Growth the World Over: Timeseries Evidence on the Happiness-income Paradox. IZA Discussion Paper No. 4060. Institute for the Study of Labour, Bonn. 
Easterlin, R. A., McVey, L. A., Switek, M., Sawangfa, O., and Zweig, J. S. (2010). The happiness-income paradox revisited. Proceedings of the National Academy of Sciences of the United States of America, 107(52): 22463-22468.

Easterlin, R. A., Morgan, R., Switek, M., and Wang, F. (2012). China's life satisfaction, 1990-2010. Proceedings of the National Academy of Sciences, 109(25): 9775-9780.

Fafchamps, M. and Kebede, B. (2008). Subjective well-being, disability and adaptation: A case study from rural Ethiopia. in Adaptation and Well-Being, David Clark (ed.), Cambridge University Press.

Fafchamps, M. and Shilpi, F. (2009). Isolation and subjective welfare: evidence from South Asia. Economic Development and Cultural Change, 57(4): 641-683.

Feng, S.Z, Hu, Y.Y. and Moffitt, R. (2015). Long run trends in unemployment and labour force participation in China. NBER Working Paper No. 21460.

Ferrer-i-Carbonell, A. (2005). Income and well-being: an empirical analysis of the comparison income effect. Journal of Public Economics, 89: 997-1019.

Frank, R.H. (1985). The demand for unobservable and other non-positional goods. American Economic Review, 75:101-116.

Frijters, P. and Beatton, T. (2012). The mystery of the U-shaped relationship between happiness and age. Journal of Economic Behavior and Organization, 82(2-3): 525-542.

Frijters, P., Liu, Y.C. and Meng, X. (2012). Are optimistic expectations keeping the Chinese happy?. Journal of Economic Behavior \& Organization, 81(1): 159-171.

Giles, J., Park, A. and Zhang, J. (2005). What is China's true unemployment rate?. China Economic Review, 16(2): 149-170.

Graham, C. (2008). Happiness and health: lessons-and questions-for public policy. Health affairs. 27(1):72-87.

Graham, C. and Felton, A. (2009). Does inequality matter to individual welfare? an initial exploration based on happiness surveys from Latin America. In Dutt, A.K. and Radcliff, B. (Eds.). Happiness, economics and politics: towards a multi-disciplinary approach. 158-201. Edward Elgar Publishing.

Guillen-Royo, Monica (2011). Reference group consumption and the subjective wellbeing of the poor in Peru. Journal of Economic Psychology, 32(2): 259-272.

Graham, C. and Pettinato, S. (2002). Frustrated achievers: winners, losers and subjective well-being in new market economies. Journal of Development Studies, 38(4): 100-140.

Guriev, S.M., and Zhuravskaya, E. (2009). (Un)Happiness in transition. Journal of Economic Perspectives, 23(2): 143-68. 
Harrell, S. (1996). Cultural encounters on China's ethnic frontiers. Seattle: University of Washington Press.

Haushofer, J., Reisinger, J. and Shapiro, J. (2015). Your gain is my pain: negative psychological externalities of cash transfers (unpublished).

https://www.princeton.edu/ joha/publications/Haushofer_Reisinger_Shapiro_Inequality_ 2015.pdf. Accessed on Nov 15th, 2015.

Hayo, B. (2007). Happiness in transition: An empirical study on Eastern Europe. Economic Systems, 31 (2): 204-221.

He, Y. (2000). The subjective happiness of college student and its determinants in Chongqing. Journal of Qingqing Teachers College, 19(2): 35-38.

Helliwell, J. (2003). How's life? combining individual and national variables to explain subjective well-being. Economic Modelling, 20(2): 331-360.

Helliwell, J. (2006). Well-being, social capital and public policy: what's new?. The Economic Journal, 116(510): C34-45.

Ivlevs, A. (2014). Economic insecurity in transition: a primary commodities perspective. Review of Income and Wealth, 60(S1): S117-S140.

Jiang, S., Lu, M. and Sato, H. (2012). Identity, inequality, and happiness: evidence from urban China. World Development, 40(6): 1190-1200.

Johnson, W. and Krueger, R.F. (2006). How money buys happiness: genetic and environmental processes linking finances and life satisfaction. Journal of Personality and Social Psychology, 90(4): 680-691.

Kahneman, D. and Krueger, A.B. (2006). Developments in the measurement of subjective well-being. Journal of Economic Perspectives, 20(1): 3-24.

Kahneman, D., Krueger, A.B., Schkade, D., Schwarz, N. and Stone, A.A. (2006). Would you be happier if you were richer? a focusing illusion, Science, 312(5782): 1908-1910.

Kahneman, D. and Deaton, A. (2010) High income improves evaluation of life but not emotional well-being. Proceedings of the National Academy of Sciences of the United States of America. 107(38):16489-16493.

Kingdon, G. and Knight, J. (2006). Subjective well-being poverty vs. income poverty and capabilities poverty?. The Journal of Development Studies, 42(7): 1199-1224.

Kingdon, G. and Knight, J. (2007). Community, comparisons and subjective well-being in a divided society. Journal of Economic Behavior and Organization, 64(1): 69-90.

Knight, J. and Gunatilaka, R. (2010). Great expectations? The subjective well-being of rural-urban migrants in China. World Development, 38(1):113-124. 
Knight, J. and Gunatilaka, R. (2011). Does economic growth raise happiness in China?. Oxford Development Studies, 39(1): 1-24.

Knight, J. and Gunatilaka, R. (2012). Income, aspirations and the hedonic treadmill in a poor society. Journal of Economic Behavior and Organization, 82(1): 67-81.

Knight, J., and Gunatilaka, R. (2014). Subjective well-being and social evaluation in a poor country. CSAE Working Paper Series No.09, Centre for the Study of African Economies, University of Oxford.

Knight, J., Li, S. and Chang, Y. (2014). Minorities in rural China: poorer but inherently happier?. CSAE Working Paper Series No.26, Centre for the Study of African Economies, University of Oxford.

Knight, J., Song, L. and Gunatilaka, R. (2009). Subjective well-being and its determinants in rural China. China Economic Review, 20(4): 635-649.

Li, H., Liu, P., Ye, M., and Zhang, J. (2014). Does Money Buy Happiness? Evidence from Twins in Urban China. Manuscript, Harvard University.

Li, Z.T., Folmer, H. and Xue, J.H. (2014). To what extent does air pollution affect happiness? The case of the Jinchuan mining area, China. Ecological Economics. 99:8899.

Liu, Q. (2012). Unemployment and labour force participation in urban China. China Economic Review, 23(1): 18-33.

Liu, Z.Q., and Shang, Q.Y (2012). Individual well-being in urban China: The role of income expectations. China Economic Review, 23(4), 833-849.

Liu, J.Q., Xiong, M.L. and Su, Y. (2013). National happiness at a time of economic growth: a tracking study based on CGSS data. Social Sciences in China, 34(4): 20-37.

Liu, R. and Gong, Y. (2000). A study on the subjective happiness of elderly and its determinants. Chinese Journal of Clinical Psychology, 8(2): 73-78.

Liu, R. and Gong, Y. (2001). A study of relation between subjective happiness and stress level of elderly. Chinese Mental Health Journal, 15(1): 28-30.

Long, J.S. and Freese, J. (2005). Regression models for categorical dependent variables using stata. Stata Press:Texas.

Mangyo, E. and Park, A. (2011). Relative deprivation and health: which reference groups matter?. Journal of Human Resources, 46(3):459-481.

Mei, J. (1999). The social determinants of happiness of elderly. Chinese Mental Health Journal, 13(2): 85-87. 
Mishra, V., Nielsen, I. and Smyth, R. (2014). How does relative income and variations in short-run well-being effect well-being in the long run? empirical evidence from China's Korean Minority. Social Indicators Research, 115(1): 67-91.

Mishra, V. and Smyth, R. (2014). It pays to be happy (If you are a man): subjective wellbeing and gender wage gap in urban China. International Journal of Manpower, 35(3): 392-414.

Namazie, C. and Sanfey, P. (2001). Happiness and transition: the case of Kyrgyzstan. Review of Development Economics, 5(3): 392-405.

Oshio, T., Nozaki,K. and Kobayashi, M.(2013). Division of household labour and marital satisfaction in China, Japan, and Korea. Journal of Family and Economic Issues, 34(2): 211-223.

Oswald, A. J. (1997). Happiness and economic performance. Economic Journal, 107(445): 1815-1831.

Powdthavee, N. (2009). How much does money really matter? Estimating the causal effects of income on happiness. Empirical Economics, 39(1): 77-92.

Ravallion, M. and Lokshin, M. (2010). Who cares about relative deprivation?. Journal of Economic Behavior and Organization, 73(2): 171-18

Rodriguez-Pose, A. and Maslauskaite, K. (2012). Can policy make us happier? Individual characteristics, socio-economic factors and life satisfaction in Central and Eastern Europe. Cambridge Journal of Regions, Economy and Society, 5 (1): 77-96.

Sanfey, P. and Teksoz, U. (2007). Does transition make you happy?. Economics of Transition, 15(4): 707-731.

Selezneva, E. (2011). Surveying transitional experience and subjective well-being: Income, work, family. Economic Systems, 35(2): 139-157.

Stevenson, B. and Wolfers, J. (2009). The paradox of declining female happiness. American Economic Journal: Economic Policy, 1(2): 190-225.

Stevenson, B. and Wolfers, J. (2013). Subjective Well-Being and Income: Is There Any Evidence of Satiation. American Economic Review, 103(3), pp. 598-604(7).

Sinning, M., Hahn, M. and Bauer, T.K. (2008). The Blinder-Oaxaca decomposition for non linear regression models, Stata Journal, 8(4): 480-492.

Smyth, R. and Qian, X.L. (2008). Inequality and Happiness in Urban China. Economics Bulletin, 4(23): 1-10.

Smyth,R., Nielsen,I., and Zhai, Q. (2010). Personal well-being in urban China. Social Indicators Research, 95(2): 231-251. 
Tang, D., Zou, J., Shen, J., and Zhang, L. (2006). The determinants of subjective happiness of elderly. Chinese Mental Health Journal, 20(3): 160-162.

Tang, J., Folmer, H. and Xue, J. (2013). Estimation of awareness and perception of water scarcity among farmers in the Guanzhong Plain, China, by means of a structural equation model. Journal of Environmental Management. 126(5):55-62.

Tang, J. and Folmer, H. (2015). Latent vs. Observed Variables: Analysis of Irrigation Water Efficiency Using SEM and SUR. Journal of Agricultural Economics. DOI: $10.1111 / 1477-9552$.

Tani, M. (2015). Hukou changes and subjective well-being. IZA Discussion Paper No. 9451. Institute for the Study of Labour, Bonn.

Tao, H. and Chiu, S. (2009). The effects of relative income and absolute income on happiness. Review of Development Economics, 13(1):164-174.

Tong, Y. (2004). A study on general self-efficacy and happiness of college student. Chinese Journal of School Health, 25(4): 396-397.

Tsai, M.C. (2009). Market openness, transition economies and subjective well-being. Journal of Happiness Studies, 10(5): 523-539.

Tsou, M.W. and Liu, J.T. (2001). Happiness and domain satisfaction in Taiwan. Journal of Happiness Studies, 2(3): 269-288.

Van Praag, B.M.S. and Frijters, P. (1999). The measurement and well-being: the Leyden approach. In Kahneman, D., Diener, E. and Schwarz, N. (Eds.), Well-being: the foundations of hedonic psychology, New York: Russel Sage Foundation.

Veenhoven, R and Hagerty, M. (2006). Rising Happiness in Nations 1946-2004 A Reply to Easterlin. Social Indicators Research, 79(3): 421-436.

Verme, Paolo (2013) The relative income and relative deprivation hypotheses: a review of the empirical literature. Policy Research Working Paper Series 6606, The World Bank.

Wang, H., Cheng, Z.M. and Smyth, R. (2013). Happiness and job satisfaction in urban China: a comparative study of two generations of migrants and urban locals. Monash University Discussion Paper No.08.

Wang, J. and Ding, X. (2003). A research on the relation between happiness and life events of junior high school student. Studies of Psychology and Behavior, 1(2): 96-99.

Wang, J. and Xie, Y. (2015). Feeling good about the iron rice bowl: economic sector and happiness in post-reform urban China. Social Science Research, 53: 203-217.

Wang, P., Pan, J. and Luo, Z. (2015). The impact of income inequality on individual happiness: evidence from China. Social Indicator Research, 121(2): 413-435. 
Wang, P. and VanderWeele, T.J. (2011). Empirical Research on Factors Related to the Subjective Well-being of Chinese Urban Residents. Social Indicators Research, 101:447459.

Wu, X.G. and Li, J. (2013). Economic growth, income inequality and subjective wellbeing: evidence from China. Population Studies Center Report 796, University of Michigan.

Xiao, J.J., Tang, C.Y. and Shim, S. (2009). Acting for happiness: financial behavior and life satisfaction of college students. Social Indicators Research, 92(1): 53-68.

Yan, B., Zheng, X. and Qiu, L. (2004). The influences of social support on the happiness of college student. Chinese Journal of Applied Psychology, 9(4): 22-28.

Yu, P., Su, S. and Li, L. (2005). Attributional style, self-efficacy and subjective happiness of college student. Chinese Journal of Clinical Psychology, 13(1):43-44.

Zhang, W. and Zheng, R. (2004). The subjective happiness of college student and its determinants. Chinese Mental Health Journal, 18(1): 61-62.

Zheng, X., Wang, L., Qiu, L. and Yan, B. (2003). The relation between subjective happiness and personality of college student. Chinese Journal of Clinical Psychology, 11(2): 105-107. 
Appendix Table 1: Descriptive Statistics and Variable Definitions

\begin{tabular}{|c|c|c|c|c|}
\hline \multirow[b]{3}{*}{ Personal characteristics } & \multirow{2}{*}{$\begin{array}{c}2010 \\
\text { Mean } \\
\end{array}$} & \multicolumn{3}{|c|}{2005} \\
\hline & & SD & Mean & SD \\
\hline & & & & \\
\hline Age & 47.509 & 15.253 & 44.682 & 14.518 \\
\hline Female $^{*}$ & 0.513 & 0.500 & 0.513 & 0.500 \\
\hline Minority $^{*}$ & 0.093 & 0.290 & 0.058 & 0.235 \\
\hline Marital status & 0.826 & 0.379 & 0.855 & 0.352 \\
\hline Unmarried ${ }^{*}$ & 0.081 & 0.272 & 0.089 & 0.284 \\
\hline Married $^{*}$ & 0.826 & 0.379 & 0.855 & 0.352 \\
\hline Divorced $^{*}$ & 0.021 & 0.143 & 0.014 & 0.116 \\
\hline Widowed $^{*}$ & 0.072 & 0.259 & 0.042 & 0.201 \\
\hline Years of education & 8.614 & 4.557 & 8.248 & 4.440 \\
\hline Number of Children & 1.782 & 1.315 & 1.458 & 1.081 \\
\hline In good health ${ }^{*}$ & 0.584 & 0.493 & 0.620 & 0.485 \\
\hline Agricultural hukou* & 0.525 & 0.499 & 0.428 & 0.495 \\
\hline \multicolumn{5}{|l|}{ Employment Status } \\
\hline In Labour Force and Employed ${ }^{*}$ & 0.645 & 0.478 & 0.650 & 0.477 \\
\hline In Labour Force but Unemployed ${ }^{*}$ & 0.049 & 0.216 & 0.133 & 0.339 \\
\hline Not in Labour Force & 0.306 & 0.461 & 0.217 & 0.413 \\
\hline \multicolumn{5}{|l|}{ Household characteristics } \\
\hline Household income pc (annual figure, in Yuan) & 17591.65 & 51492.16 & 6684.86 & 16830.28 \\
\hline House area (in sq. metre) & 106.82 & 95.20 & 94.04 & 61.54 \\
\hline Family property (number of houses) & 1.093 & 0.554 & & \\
\hline Family has car ${ }^{*}$ & 0.100 & 0.300 & 0.020 & 0.147 \\
\hline \multicolumn{5}{|l|}{ Comparison and aspiration variables } \\
\hline \multicolumn{5}{|l|}{ Family economic position } \\
\hline far above city average* & 0.004 & 0.062 & 0.008 & 0.088 \\
\hline above city average & 0.086 & 0.280 & 0.070 & 0.255 \\
\hline equal to city average ${ }^{*}$ & 0.494 & 0.500 & 0.404 & 0.491 \\
\hline below city average ${ }^{*}$ & 0.339 & 0.473 & 0.302 & 0.459 \\
\hline far below city average ${ }^{*}$ & 0.077 & 0.266 & 0.216 & 0.412 \\
\hline \multicolumn{5}{|l|}{ Personal economic position } \\
\hline better than last 10 years ${ }^{*}$ & 0.527 & 0.499 & 0.390 & 0.488 \\
\hline same as last 10 years ${ }^{*}$ & 0.328 & 0.469 & 0.411 & 0.512 \\
\hline worse than last 10 years ${ }^{*}$ & 0.145 & 0.352 & 0.199 & 0.399 \\
\hline \multicolumn{5}{|l|}{ Personal economic level } \\
\hline expect increase 10 years later & 0.633 & 0.482 & & \\
\hline expect the same 10 years later ${ }^{*}$ & 0.310 & 0.463 & & \\
\hline expect decrease 10 years later ${ }^{*}$ & 0.057 & 0.231 & & \\
\hline \multicolumn{5}{|l|}{ Geographic location } \\
\hline Rural $^{*}$ & 0.400 & 0.490 & 0.405 & 0.491 \\
\hline \multicolumn{5}{|l|}{ Province dummies } \\
\hline Beijing ${ }^{*}$ & 0.037 & 0.188 & 0.041 & 0.197 \\
\hline Tianjin ${ }^{*}$ & 0.035 & 0.185 & 0.044 & 0.205 \\
\hline Hebei $^{*}$ & 0.021 & 0.142 & 0.043 & 0.202 \\
\hline Shanxi ${ }^{*}$ & 0.027 & 0.161 & 0.015 & 0.121 \\
\hline Neimenggu ${ }^{*}$ & 0.010 & 0.099 & 0.018 & 0.134 \\
\hline Liaoning ${ }^{*}$ & 0.037 & 0.189 & 0.043 & 0.202 \\
\hline Jilin $^{*}$ & 0.045 & 0.207 & 0.018 & 0.133 \\
\hline Heilongjiang $^{*}$ & 0.053 & 0.223 & 0.021 & 0.143 \\
\hline Shanghai ${ }^{*}$ & 0.038 & 0.192 & 0.042 & 0.201 \\
\hline Jiangsu $^{*}$ & 0.046 & 0.209 & 0.067 & 0.250 \\
\hline Zhejiang ${ }^{*}$ & 0.035 & 0.183 & 0.025 & 0.158 \\
\hline Anhui $^{*}$ & 0.039 & 0.193 & 0.057 & 0.232 \\
\hline
\end{tabular}




\begin{tabular}{|c|c|c|c|c|}
\hline Fujian* & 0.027 & 0.161 & 0.033 & 0.179 \\
\hline Jiangxi $^{*}$ & 0.035 & 0.185 & 0.018 & 0.135 \\
\hline Shandong* & 0.054 & 0.227 & 0.068 & 0.252 \\
\hline Henan ${ }^{*}$ & 0.055 & 0.229 & 0.046 & 0.211 \\
\hline Hubei $^{*}$ & 0.057 & 0.231 & 0.054 & 0.226 \\
\hline Hunan $^{*}$ & 0.039 & 0.193 & 0.049 & 0.216 \\
\hline Guangdong* & 0.044 & 0.205 & 0.053 & 0.224 \\
\hline Guangxi* & 0.027 & 0.161 & 0.033 & 0.178 \\
\hline Hainan* & 0.007 & 0.085 & 0.008 & 0.089 \\
\hline Chongqing* & 0.023 & 0.150 & 0.009 & 0.095 \\
\hline Sichuan* & 0.054 & 0.226 & 0.063 & 0.242 \\
\hline Guizhou* & 0.028 & 0.164 & 0.028 & 0.164 \\
\hline Yunnan* & 0.037 & 0.189 & 0.034 & 0.180 \\
\hline Xizang $^{*}$ & 0.005 & 0.073 & & \\
\hline Shanx ${ }^{*}$ & 0.037 & 0.189 & 0.036 & 0.187 \\
\hline Gansu* & 0.020 & 0.139 & 0.026 & 0.158 \\
\hline Qinghai* & 0.010 & 0.099 & & \\
\hline Ningxia* & 0.010 & 0.099 & & \\
\hline Xinjiang ${ }^{*}$ & 0.010 & 0.099 & 0.008 & 0.089 \\
\hline $\mathrm{N}$ & 10097 & & 9061 & \\
\hline
\end{tabular}

Note: 1. Data are from the Chinese General Social Survey (CGSS). 2. "indicates dummy indicator. 
Appendix Table 2: Gender Gap in Earnings and Income, 2010-2005

\begin{tabular}{lccc}
\hline CGSS 2010 & $\begin{array}{c}\text { Total } \\
\text { earnings } \\
\text { (in Yuan) }\end{array}$ & $\begin{array}{c}\text { Non-agricultural } \\
\text { earnings } \\
\text { (in Yuan) }\end{array}$ & $\begin{array}{c}\text { Per capita } \\
\text { household income } \\
\text { (in Yuan) }\end{array}$ \\
\cline { 2 - 4 } Men & 28,995 & 37,767 & 18,944 \\
Women & 15,942 & 22,647 & 16,368 \\
Raw mean difference & 13,052 & 15,120 & 2,576 \\
$(\%$ mean difference) & $(45.02 \%)$ & $(40.03 \%)$ & $(13.60 \%)$ \\
\hline CGSS 2005 & 11,449 & 18,083 & 6,826 \\
Men & 8,149 & 15,547 & 6,190 \\
Women & 3,299 & 2,535 & 635 \\
Raw mean difference & $(28.82 \%)$ & $(14.02 \%)$ & $(9.31 \%)$ \\
(\% mean difference) & Notes: 1. All numbers correspond to annual figures. 2. Earnings data for 2005 refers to all earnings while \\
figure for 2010 refers to wage earnings. 3. Data are from the Chinese General Social Survey (CGSS).
\end{tabular}

